\title{
Synthesis and Antitumor Activity of Novel Pyrimidinyl Pyrazole Derivatives. III. ${ }^{1,2)}$ Synthesis and Antitumor Activity of 3-Phenylpiperazinyl-1-trans-propenes
}

\author{
Hiroyuki Naito, ${ }^{a}$ Satoru Ohsuki, ${ }^{a}$ Ryo Atsumi, ${ }^{b}$ Megumi Minami, ${ }^{c}$ Mineko Mochizuki, ${ }^{c}$ \\ Kenji Hirotani, ${ }^{d}$ Eiji Kumazawa, ${ }^{c}$ and Akio EJima ${ }^{*, a}$ \\ ${ }^{a}$ Medicinal Chemistry Research Laboratory, Daiichi Pharmaceutical Co. Ltd.; ${ }^{b}$ Drug Metabolism \& Physicochemical \\ Property Research Laboratory, Daiichi Pharmaceutical Co. Ltd.; ${ }^{c}$ New Product Research Laboratories III, Daiichi \\ Pharmaceutical Co. Ltd.; and ${ }^{d}$ Discovery Research Laboratory, Daiichi Pharmaceutical Co. Ltd.; 1-16-13 Kita-kasai, \\ Edogawa-ku, Tokyo 134-8630, Japan. Received July 20, 2004: accepted November 6, 2004
}

A series of novel 3-[4-phenyl-1-piperazinyl]-1-[5-methyl-1-(2-pyrimidinyl)-4-pyrazolyl]-1-trans-propenes and related compounds were synthesized and evaluated by their cytotoxic activity against several tumor cell lines in vitro and in vivo antitumor activity against some tumor models when administered both intraperitoneally and orally. Compounds with the 3-chloropyridin-2-yl group $(9 \mathrm{~g})$ and the 3-fluoro-5-substituted phenylpiperazinyl group (29b, c, and e) showed significantly potent cytotoxicity by in vitro testing. Among them, the 3-cyano-5-fluorophenyl derivative $(29 \mathrm{~b})$ exhibited potent antitumor activity against several tumor cells including human carcinoma without causing undesirable effects in mice.

Key words cytotoxic activity; antitumor activity; structure-activity relationship

In previous papers, we reported novel pyrimidinyl pyrazole derivatives (Fig. 1) that showed in vitro and in vivo antitumor activity. These compounds were also found to inhibit tubulin polymerization as a mechanism of their action in cells. ${ }^{1,2)}$ To investigate the possibilities for modification of this scaffold, we divided the moieties into five parts from $\mathrm{A}$ to $\mathrm{E}$ as shown in Fig. 1. So far, it has been reported that the length of the three carbon chain on moiety $\mathrm{C}$ and the existence of piperazine on moiety D are important for the activity. In an effort to improve the activity, we replaced the pyrimidine and pyrazole moieties of A and B with some heteroaryl moieties and introduced various substituents to the phenyl ring of moiety E. We describe here the modification of moieties A, B, and $\mathrm{E}$ and the antitumor activities of the resulting compounds.

\section{Chemistry}

Syntheses of the 1-arylpyrazolyl compounds $(9 \mathbf{a}-\mathbf{k})$ were carried out via the route shown in Chart 1 . The hydrazine derivatives $(\mathbf{5 a}-\mathbf{j})^{3-7)}$ were subjected to the construction of a pyrazole ring with ethoxymethyleneacetylacetone ${ }^{8)}$ to provide the 4-acetyl-1-heteroarylpyrazoles $(\mathbf{6 a}-\mathbf{j})$. Phenylpyrazole derivative (6k) was prepared by following the reported

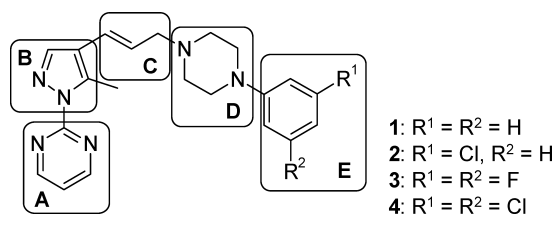

Fig. 1

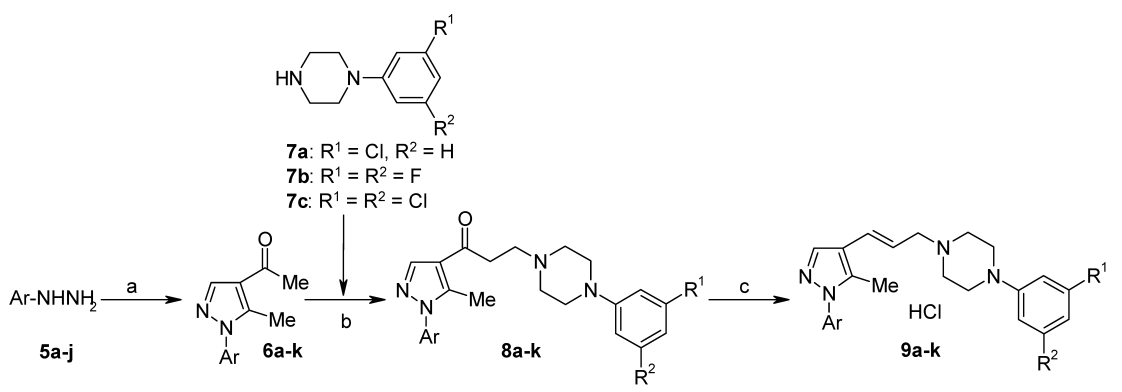

\begin{tabular}{|c|c|c|c|c|c|c|c|c|c|c|c|c|c|c|c|}
\hline & $-\mathrm{Ar}$ & $\mathrm{R}^{1}$ & $\mathrm{R}^{2}$ & & $-A r$ & $\mathrm{R}^{1}$ & $\mathrm{R}^{2}$ & & $-A r$ & $\mathrm{R}^{1}$ & $\mathrm{R}^{2}$ & & $-A r$ & $\mathrm{R}^{1}$ & $\mathrm{R}^{2}$ \\
\hline $\mathbf{a}$ & & $\mathrm{Cl}$ & $\mathrm{H}$ & b & & $\mathrm{Cl}$ & $\mathrm{H}$ & c & & $\mathrm{Cl}$ & $\mathrm{H}$ & d & & $\mathrm{Cl}$ & $\mathrm{H}$ \\
\hline e & & $\mathrm{Cl}$ & $\mathrm{H}$ & $f$ & & $\mathrm{Cl}$ & $\mathrm{H}$ & $\mathbf{g}$ & & $F$ & $F$ & h & & $\mathrm{F}$ & $F$ \\
\hline i & & $F$ & $F$ & $\mathbf{j}$ & & $F$ & $F$ & k & & $\mathrm{Cl}$ & $\mathrm{Cl}$ & & & & \\
\hline
\end{tabular}

a) ethoxymethyleneacethylacetone, $\mathrm{EtOH}, \mathrm{b})(\mathrm{HCHO}) n, \mathrm{HCl}, \mathrm{EtOH}, \mathrm{c})$ 1) $\mathrm{NaBH}_{4}, \mathrm{EtOH} / \mathrm{THF}$, 2) $p$-TsOH$\cdot \mathrm{H}_{2} \mathrm{O}, 1,4$-dioxane, THF, 3) $\mathrm{HCl} / \mathrm{EtOH}$. 
procedure. ${ }^{9,10)}$ Mannich reaction of pyrazoles $(\mathbf{6 a}-\mathbf{k})$ with 1-(3-chlorophenyl)piperazine (7a), 1-(3,5-difluorophenyl)piperazine $(\mathbf{7 b})$, or 1-(3,5-dichlorophenyl)piperazine (7c) gave $8 \mathbf{a}-\mathbf{k}$, respectively. Compounds $(\mathbf{8 a}-\mathbf{k})$ were reduced with sodium borohydride to give the corresponding alcohols, which were dehydrated by $p$-toluenesulfonic acid ( $p$-TsOH) to afford 1-trans-propene derivatives $\mathbf{9 a}-\mathbf{k}$.

Modification of the pyrazole moiety was carried out via the route shown in Charts 2 and 3. Compound (11), which was prepared by iodination of 2-(1-pyrazolyl)pyrimidine (10) ${ }^{11)}$ with periodic acid, afforded 12 through a palladiumcatalyzed cross-coupling reaction with vinyltributylstannum in the presence of lithium chloride. ${ }^{12)}$ Compound (12) was treated with sulfuric acid and then oxidized with manganese (IV) oxide to afford 5-demethylpyrazole (15a). Migration of the pyrimidinyl group of $\mathbf{1 3}{ }^{1,2)}$ to the 2-position from the 1position on the pyrazole ring was carried out by using diethyl carbonate and sodium hydride to produce 3-methylpyrazole (15b). Dimethylpyrazole (15c) was prepared following the reported procedure. ${ }^{13)}$ To investigate the possibility of replacing the pyrazole ring with a pyrrole ring, 1-(2-methyl- $1 \mathrm{H}$ - pyrrol-3-yl)ethanone (14) ${ }^{14,15)}$ was reacted with 2-chloropyrimidine to afford 2-methylpyrrole (15d). The derivatives bearing a pyrazole ring $(\mathbf{1 7 a}-\mathbf{c})$ and a pyrrole ring $(\mathbf{1 7 d})$ were obtained from the 4-acetylpyrazole derivatives $(15 \mathbf{a}-\mathbf{c})$ and the pyrrole derivative (15d) with modified piperazines (7a) and (7c) via the Mannich reaction and dehydration, respectively (Chart 2).

Furthermore, the imidazole derivative (23) having a nitrogen atom at 3-position of the pyrazole ring was also prepared by the procedure to construct this scaffold by employing reductive amination instead of the Mannich reaction (Chart 3). Ethyl 4-methyl-5-imidazolecarboxylate (18) was condensed with 2-chloropyrimidine to afford pyrimidinylimidazole (19). Reduction of 19 with diisobutylaluminum hydride (DIBAL) gave aldehyde (20). The carbon-carbon bond formation of 20 with allyl bromide was performed with metallic stannum, ${ }^{16)}$ followed by protection of the secondary alcohol with triethylsilyl chloride to give 21. Oxidation of 21 with osmium tetraoxide $\left(\mathrm{OsO}_{4}\right)$ and simultaneous oxidative cleavage of the 1,2-diol with sodium periodate gave aldehyde (22). The reductive amination of $\mathbf{2 2}$ with $\mathbf{7 b}$ by treatment with

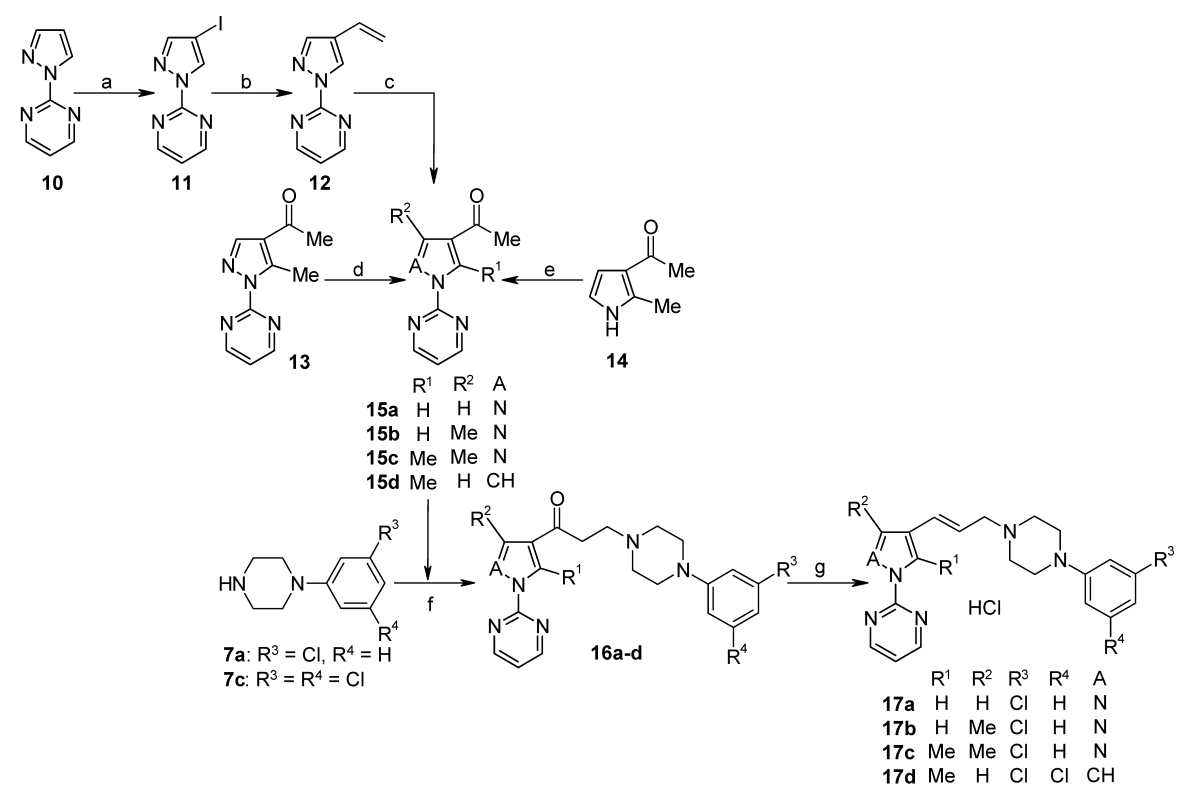

a) $\mathrm{HIO}_{4}, \mathrm{I}_{2}, \mathrm{H}_{2} \mathrm{SO}_{4}-\mathrm{AcOH}$, b) vinyltributylstannum, $\left(\mathrm{Ph}_{3} \mathrm{P}\right)_{4} \mathrm{Pd}$, $\mathrm{LiCl}$, 1,4-dioxane, c) 1) $\left.\mathrm{CH}_{2} \mathrm{SO}_{4}, 2\right) \mathrm{MnO}_{4}$, 1,4-dioxane, d) $(\mathrm{EtO})_{2} \mathrm{CO}$, $\mathrm{NaH}, \mathrm{PhMe}, \mathrm{e})$ 2-chloropyrimidine, $\mathrm{KOH}$, DMSO, f) (HCHO)n, $\mathrm{HCl}, \mathrm{EtOH}, \mathrm{g})$ 1) $\left.\mathrm{NaBH}_{4}, \mathrm{EtOH} / \mathrm{THF}, 2\right) p$ - $\mathrm{TsOH} \cdot \mathrm{H}_{2} \mathrm{O}, 1,4-\mathrm{Dioxane}$, THF, 3) $\mathrm{HCl} / \mathrm{EtOH}$.

Chart 2

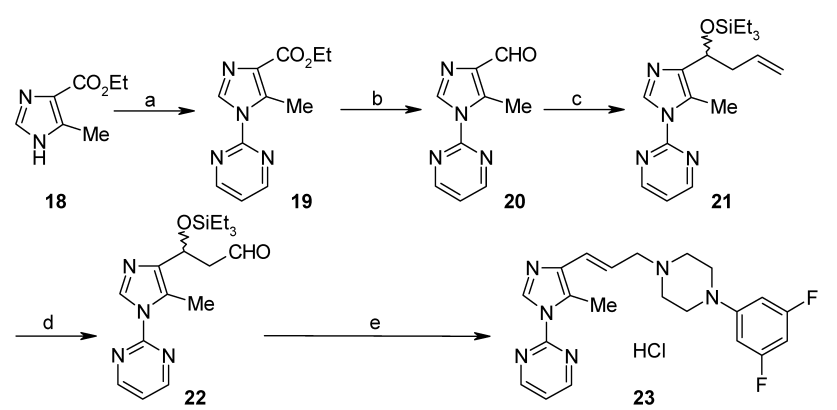

a) 2-chloropyrimidine, $\mathrm{K}_{2} \mathrm{CO}_{3}, \mathrm{DMF}$, b) DIBAL, $\mathrm{THF} / \mathrm{CH}_{2} \mathrm{Cl}_{2}$, c) 1) allylbromide, $\left.\mathrm{Sn}, \mathrm{H}_{2} \mathrm{O} / \mathrm{THF}, 2\right) \mathrm{Et}_{3} \mathrm{SiCl}$, imidazole, DMF, d) 1) $\mathrm{OsO}_{4}$ (cat.), $\mathrm{NMO}, \mathrm{H}_{2} \mathrm{O} / \mathrm{THF}$, 2) $\mathrm{NalO}_{4}, \mathrm{H}_{2} \mathrm{O} / \mathrm{THF}$, e) 1) $7 \mathrm{~b}, \mathrm{NaBH}_{3} \mathrm{CN}, \mathrm{AcOH}, \mathrm{MeOH}, 2$ ) $\mathrm{HCl} / \mathrm{EtOH}$. 


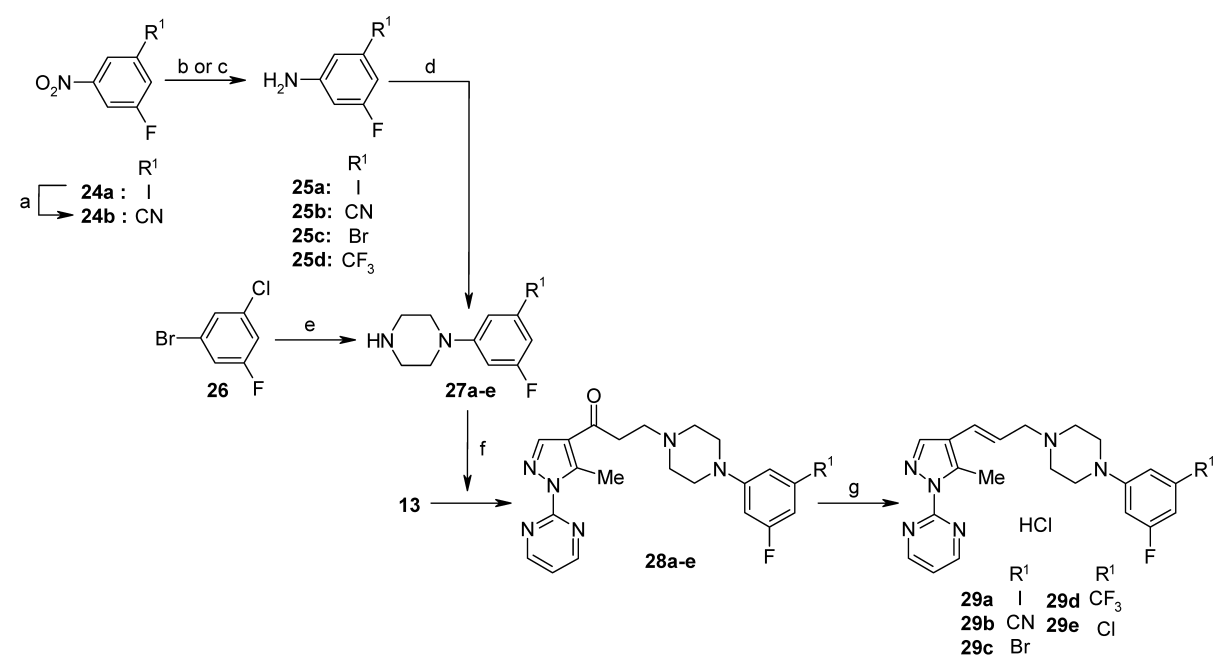

a) $\mathrm{CuCN}, \mathrm{DMF}$, b) $\left.\mathrm{SnCl}_{2} \cdot 2 \mathrm{H}_{2} \mathrm{O}, \mathrm{EtOH}, \mathrm{c}\right) \mathrm{H}_{2} / \mathrm{Pd}-\mathrm{C}, \mathrm{EtOH}$, d) bis(chloroethyl)amine, $\mathrm{K}_{2} \mathrm{CO}_{3}, n$ - BuOH, e) piperazine, $\mathrm{PdCl} 2\left[\mathrm{P}\left(\mathrm{o}-\mathrm{tol}_{3}\right]_{2}\right.$, $t$-BuONa, 1,4-dioxane, f) $(\mathrm{HCHO}) n, \mathrm{HCl}, \mathrm{EtOH}, \mathrm{g})$ 1) $\mathrm{NaBH}_{4}$, EtOH/THF, 2) $p$ - $\mathrm{TsOH} \cdot \mathrm{H}_{2} \mathrm{O}, 1,4$-dioxane, THF, 3) $\mathrm{HCl} / \mathrm{EtOH}$.

Chart 4

sodium cyanoborohydride in acetic acid $(\mathrm{AcOH}) / \mathrm{EtOH}$ gave the corresponding adduct, followed by deprotection and simultaneous dehydration with hydrochloride to afford the 1trans-propene derivative (23).

On the other hand, some 3,5-disubstituted phenylpiperazine derivatives were synthesized via the route shown in Chart 4, because 3,5-disubstitution of phenylpiperazine enhanced activity. As for the introduction of cyanide, 1-fluoro3-iode-5-nitrobenzene (24a) was reacted with copper(I) cyanide to afford 1-cyano-3-fluoro-5-nitrobenzene (24b). After reduction of the nitro group of compounds $(\mathbf{2 4 a}, \mathbf{b})$, the anilines $(\mathbf{2 5 a}-\mathbf{d})$ were treated with bis(2-chloroethyl)amine hydrochloride and potassium carbonate to give the phenylpiperazines $(\mathbf{2 7} \mathbf{a}-\mathbf{d})$. Compound $(\mathbf{2 7 e})$ was prepared via a palladium(II)-catalyzed aromatic amination reaction ${ }^{17)}$ of 1-bromo-3-chloro-5-fluorobenzene (26) with piperazine. Mannich reaction of $\mathbf{1 3}$ with 3,5-disubstituted phenylpiperazines $(27 \mathbf{a}-\mathbf{e})$ gave $\mathbf{2 8 a}-\mathbf{e}$, respectively. Propene derivatives $(\mathbf{2 9} \mathbf{a}-\mathbf{e})$ were obtained from $28 \mathbf{a}-\mathbf{e}$ by the same procedure as described in Chart 1.

\section{Biological Activity and Discussion}

The in vitro cytotoxic activity of these compounds was measured by using the human lung cancer cell lines PC-6 and $\mathrm{PC}-12$, and the concentrations producing a $50 \%$ growth inhibitory effect $\left(\mathrm{GI}_{50}\right)$ are listed in Table 1. Compounds (24), VCR, and 5-fluorouracil (5-FU) were used as reference compounds.

Among a series of 1-arylpyrazole derivatives $(9 \mathbf{a}-\mathbf{f})$ bearing the 3-chlorophenylpiperazine moiety, the pyridine derivatives $(\mathbf{9 a}, \mathbf{b})$, and the pyrazine derivative $(\mathbf{9 c})$ showed weak activity, while the other compounds $(\mathbf{9 d}-\mathbf{f})$ were not active. On the other hand, in a series of 1-arylpyrazole compounds $(9 \mathrm{~g}-\mathbf{j})$ bearing the 3,5-difluorophenylpiperazine moiety, the 3 -chloropyridin-2-yl derivative (9g) showed similar activity and potency to that of the corresponding pyrimidin-2-yl derivative (3). The activities of compounds $(9 \mathbf{h}-\mathbf{j})$ bearing a 3chloropyridin-4-yl, 3,5-dichloropyridin-4-yl, and 5-chloropyridin-2-yl moiety, respectively, were moderate or inactive. The phenylpyrazole compound (9k) had decreased activity
Table 1. Cytotoxic Activity of 1-trans-Propene Derivatives

\begin{tabular}{|c|c|c|}
\hline \multirow{2}{*}{ Compd. No. } & \multicolumn{2}{|c|}{$\left.\mathrm{GI}_{50}(\mathrm{ng} / \mathrm{ml})^{a}\right)$} \\
\hline & PC-6 & PC-12 \\
\hline $9 \mathbf{a}$ & 306 & $\mathrm{NT}^{b)}$ \\
\hline $9 b$ & 127 & 589 \\
\hline $9 c$ & 113 & 583 \\
\hline 9d & $>1000$ & $>1000$ \\
\hline $9 e$ & $>1000$ & $>1000$ \\
\hline $9 f$ & $>1000$ & $>1000$ \\
\hline $9 \mathrm{~g}$ & 8.8 & 35 \\
\hline $9 \mathrm{~h}$ & 31 & 109 \\
\hline $9 \mathbf{i}$ & $>1000$ & $>1000$ \\
\hline $9 \mathbf{j}$ & 57 & 358 \\
\hline $9 k$ & 455 & $>1000$ \\
\hline $17 \mathbf{a}$ & $>1000$ & $>1000$ \\
\hline $17 b$ & $>1000$ & $>1000$ \\
\hline $17 \mathrm{c}$ & 461 & $>1000$ \\
\hline $17 d$ & 691 & $>1000$ \\
\hline 23 & $>1000$ & $>1000$ \\
\hline $29 a$ & 104 & 667 \\
\hline $29 b$ & 4.8 & 27 \\
\hline $29 c$ & 5.4 & 75 \\
\hline 29d & 40 & 370 \\
\hline $29 e$ & 2.5 & 22 \\
\hline 2 & 34 & 208 \\
\hline 3 & 6.4 & 63 \\
\hline 4 & 6.3 & 205 \\
\hline VCR & 0.3 & 33 \\
\hline $5-\mathrm{FU}$ & 460 & 30 \\
\hline
\end{tabular}

PC-6, PC-12: Human non-small cell lung cancer cell lines. a) See Experimental. b) NT: not tested.

compared with that of the pyrimidinylpyrazole compound (4). The pyrimidin-2-yl part and the 3-chloropyridin-2-yl part on moiety A are important for potent activity, because all the other derivatives showed decreased in vitro activity compared with the corresponding pyrimidine derivatives.

As for the modification of moiety B, compound (17c) having methyl groups at both 3-and 5-positions of pyrazole showed weak in vitro cytotoxic activity, while the corresponding compounds (17a) without methyl group and (17b) with a methyl group at 3-position of pyrazole were not ac- 
tive. The fact that compounds $(\mathbf{2})$ and $(\mathbf{1 7 c})$ retained the cytotoxic activity, while no activity was observed with $\mathbf{1 7} \mathbf{a}$ and $\mathbf{b}$, indicates that a methyl group at 5-position of pyrazole plays a critical role for showing cytotoxic activity. Replacement of the pyrazole ring with the pyrrole or imidazole ring caused a decrease of cytotoxic activity (17d, 23), even though these compounds had a methyl group at the same position. It seemed to be very difficult to retain in vitro activity by changing the structure of moiety B.

In the series of 3-fluoro-5-substituted phenyl derivatives $(29 \mathbf{a}-\mathbf{e})$ listed in Chart 4 , compounds $(\mathbf{2 9} \mathbf{b}, \mathbf{e})$ which bear a cyano or a chloro group at the same position of the phenyl ring, showed slightly enhanced activity compared with the corresponding 3,5-difluorophenyl derivative (3) against PC-6 and PC-12. The 3-bromo-5-fluorophenyl derivative (29c) showed almost the same activity as $\mathbf{3}$, but the iodo substituent at 3-position dramatically decreased the in vitro activity (29a). The activity of the corresponding compound (29d) bearing the trifluoromethyl group at the same position of the phenyl ring was moderate.

Compounds $(9 \mathrm{~g}),(29 \mathrm{~b}),(29 \mathrm{c})$, and $(29 \mathrm{e})$, which showed strong in vitro cytotoxic activity, were tested in the in vivo assay against murine fibrosarcoma Meth $\mathrm{A}$ as a solid tumor model by intraperitoneal injection or oral administration. 5-FU was used as a reference compound.

As shown in Table 2, all compounds exhibited more potent antitumor activity at the maximum tolerated dose (MTD) than that $(26 \%)$ of 5 -FU by intraperitoneal injection. Particularly, compound (29b) exhibited potent effect with the respective inhibition rate (IR) value of $75 \%$ at the MTD, the antitumor activity of 29b was superior to those of $\mathbf{2}$ and $\mathbf{3}$ when administered intraperitoneally. The effect of $9 g, 29 c$, and $29 \mathrm{e}$, however, was moderate in spite of showing activity almost equal to the in vitro cytotoxic activity of $\mathbf{2 9 b}$. These compounds also did not cause a decrease of body temperature as the side effect at the level of each MTD. Furthermore, muscle relaxation and crouching posture were not observed for these compounds at the MTD in mice, although the lead compound (2) in this scaffold caused these visible symptoms. The tumor growth inhibition curves of $29 \mathbf{b}$ and 5-FU are shown in Fig. 2.

When administered orally, the effects of these compounds

Table 2. Antitumor Activity of 1-trans-Propene Derivatives against Murine Fibrosarcoma Meth $\mathrm{A}^{a)}$

\begin{tabular}{|c|c|c|c|c|c|c|c|c|}
\hline \multirow{3}{*}{ Compd. No. } & \multicolumn{8}{|c|}{ Antitumor activity $^{b}$ ) } \\
\hline & \multicolumn{4}{|c|}{ i.p. } & \multicolumn{4}{|c|}{ p.o. } \\
\hline & Dose (mg/kg) & $\operatorname{IR}(\%)$ & BWLmax $^{c)}(\%)$ & $\mathrm{D} / \mathrm{U}^{d)}$ & Dose $(\mathrm{mg} / \mathrm{kg})$ & $\operatorname{IR}(\%)$ & BWLmax $(\%)$ & $\mathrm{D} / \mathrm{U}$ \\
\hline \multirow[t]{2}{*}{$9 \mathrm{~g}$} & $35.0 \times 5$ & $47 *$ & $<0$ & $0 / 7$ & $60.0 \times 5$ & $89 * * *$ & 15.0 & $1 / 7$ \\
\hline & $28.0 \times 5$ & $34 *$ & $<0$ & $0 / 7$ & $35.0 \times 5$ & $55^{* *}$ & $<0$ & $0 / 7$ \\
\hline \multirow[t]{2}{*}{ 29b } & $10.0 \times 5$ & $75 * * *$ & 14.2 & $0 / 7$ & $10.0 \times 5$ & $86^{* * *}$ & 12.3 & $0 / 7$ \\
\hline & $7.0 \times 5$ & $58 * *$ & 1.2 & $0 / 7$ & $7.0 \times 5$ & $72 * *$ & 2.0 & $0 / 7$ \\
\hline $29 c$ & $60.0 \times 5$ & $43 * *$ & 2.0 & $0 / 7$ & & & & \\
\hline \multirow[t]{2}{*}{$29 \mathrm{e}$} & $20.0 \times 5$ & $51 * *$ & 1.6 & $0 / 7$ & $30.0 \times 5$ & $81 * * *$ & 3.5 & $0 / 7$ \\
\hline & $14.0 \times 5$ & $43 * *$ & $<0$ & $0 / 7$ & $20.0 \times 5$ & $57 * *$ & $<0$ & $0 / 7$ \\
\hline \multirow[t]{2}{*}{$5-\mathrm{FU}^{1,2)}$} & $40.0 \times 5$ & 66 & 27.0 & $6 / 7$ & $60.0 \times 5$ & 80 & 25.4 & $3 / 7$ \\
\hline & $20.0 \times 5$ & 26 & 9.2 & $0 / 7$ & $40.0 \times 5$ & $40 * *$ & 14.5 & $0 / 7$ \\
\hline
\end{tabular}

Inhibition rate (IR) of VCR; $9.0 \%\left(1.6 \mathrm{mg} / \mathrm{kg}\right.$, i.v.), $2 ; 62 \%\left(43 \times 5 \mathrm{mg} / \mathrm{kg}\right.$, i.p.) and $88 \%(60 \times 5 \mathrm{mg} / \mathrm{kg}$, p.o. $), 3 ; 63 \%(7.4 \times 5 \mathrm{mg} / \mathrm{kg}, \mathrm{i} . \mathrm{p}$.$) and 86 \%(12.5 \times 5 \mathrm{mg} / \mathrm{kg}$, p.o. $){ }^{1,2)} \quad$ a $)$ Murine fibrosarcoma Meth A cells $\left(1 \times 10^{6}\right.$ cells $/ 0.1 \mathrm{ml} /$ head) were implanted into the right flank of BALB/c mice (day 0$)$. Pyrimidinylpyrazole derivatives at the indicated doses were administered intraperitoneally (i.p.) or per os (oral) administration (p.o.) on days 7-11, consecutively. b) See Experimental. $c$ ) Rate of body weight loss (BML). $d$ ) Number of mice that died of toxicity/number of mice used. $* * * p<0.001, * * p<0.01, * p<0.05 v s$. the control group.
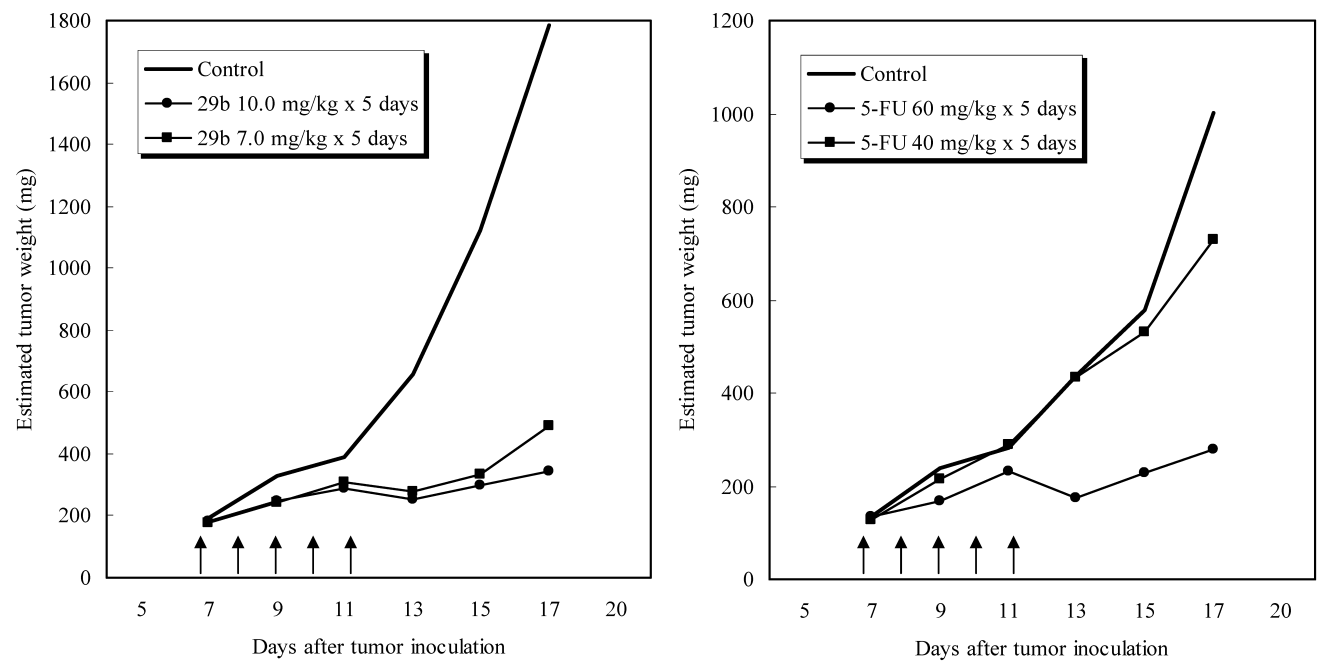

Fig. 2. Tumor Growth Inhibition Curves of 29b and 5-FU' ${ }^{1)}$ against Meth A

Murine fibrosarcoma Meth A cells $\left(1 \times 10^{6}\right.$ cells $\left./ 0.1 \mathrm{ml} / \mathrm{head}\right)$ were implanted into the right flank of BALB/c mice (day 0$)$. Compound $29 \mathrm{~b}$ and 5 -FU at the indicated doses were administered orally on days $7-11$, consecutively. 
Table 3. Antitumor Effect of $\mathbf{3}$ and $\mathbf{2 9} \mathbf{b}$ on Human Carcinoma in Nude Mice ${ }^{a}$

\begin{tabular}{|c|c|c|c|c|c|c|c|c|c|c|c|c|}
\hline & \multicolumn{12}{|c|}{ Antitumor activity $\left.{ }^{b}\right)$} \\
\hline & \multicolumn{4}{|c|}{$29 b$} & \multicolumn{4}{|c|}{3} & \multicolumn{4}{|c|}{ VCR } \\
\hline & $\begin{array}{c}\text { Dose } \\
(\mathrm{mg} / \mathrm{kg})\end{array}$ & $\begin{array}{l}\text { IR } \\
(\%)\end{array}$ & $\begin{array}{c}\text { BWLmax }^{c)} \\
(\%)\end{array}$ & $\mathrm{D} / \mathrm{U}^{d)}$ & $\begin{array}{c}\text { Dose } \\
(\mathrm{mg} / \mathrm{kg})\end{array}$ & $\begin{array}{l}\text { IR } \\
(\%)\end{array}$ & $\begin{array}{c}\text { BWLmax }^{c)} \\
(\%)\end{array}$ & $\mathrm{D} / \mathrm{U}^{d)}$ & $\begin{array}{c}\text { Dose } \\
(\mathrm{mg} / \mathrm{kg})\end{array}$ & $\begin{array}{l}\text { IR } \\
(\%)\end{array}$ & $\begin{array}{c}\left.\text { BWLmax }^{c}\right) \\
(\%)\end{array}$ & $\left.\mathrm{D} / \mathrm{U}^{d}\right)$ \\
\hline PC-12 & $8.0 \times 8$ & $70 * * *$ & 1.0 & $0 / 5$ & $10.0 \times 8$ & $68 * * *$ & 3.1 & $0 / 6$ & $1.6 \times 1$ & -10 & 17.2 & $0 / 6$ \\
\hline PC-14 & $8.0 \times 8$ & $38 *$ & 2.8 & $0 / 6$ & $10.0 \times 8$ & $53 * *$ & 7.8 & $0 / 6$ & $1.6 \times 1$ & $53 * *$ & 15.8 & $0 / 6$ \\
\hline
\end{tabular}

a) Human non-small cell lung cancer PC-12 and PC-14 blocks were inoculated s.c. into BALB/cAnNCrj-nu mice (day 0). Compounds $\mathbf{2 9 b}$ and $\mathbf{3}$ at the indicated doses were administered per os (oral) administration (p.o.) from day 11 or 14 . VCR was administrated i.v. on day 11 or 14, once. b) See Experimental. $c$ ) Rate of body weight loss. $d$ ) Number of mice that died of toxicity/number of mice used. $* * * p<0.001, * * p<0.01, * p<0.05 v s$. the control group.

Table 4. In Vitro Cytotoxicity against Multi-Drug Resistant Cell Lines ${ }^{a, b}$

\begin{tabular}{|c|c|c|c|c|c|c|}
\hline \multirow{2}{*}{$\begin{array}{l}\text { Compd. } \\
\text { No. }\end{array}$} & \multirow{2}{*}{$\begin{array}{c}\mathrm{GI}_{50}(\mathrm{ng} / \mathrm{ml}) \\
\text { PC-6 }\end{array}$} & \multicolumn{5}{|c|}{ Rate $^{c)}$} \\
\hline & & PC-6/VCR29-9 & PC-6/ADM2-1 & PC-6/Tax 1-1 & PC-6/CDDP2-7 & PC-6/FU26-23 \\
\hline $29 b$ & 4.8 & 0.97 & 1.63 & 1.34 & 2.17 & 1.87 \\
\hline VCR & 0.101 & 842 & 691 & 398 & 2.58 & 1.60 \\
\hline ADM & 12.6 & 27.9 & 18.7 & 8.65 & 1.02 & 0.46 \\
\hline Taxol & 0.31 & 580 & 365 & 299 & 1.08 & 1.02 \\
\hline Cisplatin & 203 & 0.54 & 1.17 & 0.66 & 28.6 & 0.11 \\
\hline 5-FU & 420 & 0.85 & 1.09 & 0.78 & 0.72 & 24.8 \\
\hline
\end{tabular}

a) See Experimental. b) PC-6/VCR29-9, PC-6/ADM2-1 and PC-6/Tax1-1 overexpress P-glycoprotein. PC-6/CDDP2-7 overexpresses GSH (glutathione) and GSSG. Mechanism of 5-FU resistance in the PC-6/FU26-23 cell line is unknown. c) $\left(\mathrm{GI}_{50}\right.$ value against drug-resistant cell line $) /\left(\mathrm{GI}_{50}\right.$ value against $\mathrm{PC}-6$ cell line).

were superior to that by intraperitoneal injection (Table 2). Compounds (29b) and (29e) showed potent antitumor activity with the respective IR values of $86 \%$ and $81 \%$ at the MTD. The effects of $\mathbf{2 9 b}$ and $29 \mathrm{e}$ by oral administration were superior to that $(40 \%)$ of $5-\mathrm{FU}$ and the same as that of 2 and 3, although the effect of $\mathbf{9 g}$ was moderate at the MTD $(\mathrm{IR}=55 \%)$. The oral absorption rates of compounds $(\mathbf{9 g})$ and (29e) were evaluated by the intestinal loop method. ${ }^{18)}$ As a result, both compounds displayed high oral absorption rates of $99.8 \%(\mathbf{9 g})$ and $99.9 \%(\mathbf{2 9 e})$ compared with $87.2 \%$ of 3 and $6.2 \%{ }^{1)}$ of 4 . A fluoride atom of the phenyl ring on moiety A was considered to be essential for good oral absorption.

Furthermore, the antitumor activity of $\mathbf{2 9 b}$ was evaluated for oral administration by employing human lung carcinoma PC-12 and PC-14 in nude mice. As shown in Table 3, compound 29b exhibited significantly potent antitumor activity against PC-12 with a respective IR value of $70 \%$ at the MTD compared with that of vincristine (VCR) by intravenous injection, and the effect was almost equal to that of 3 . The tumor growth inhibition curves of $\mathbf{2 9 b}$ and $\mathbf{3}$ are shown in Fig. 3. While the antitumor activity of $\mathbf{2 9 b}$ against PC-14 was weak at the MTD ( $\mathrm{IR}=38 \%$ ), compound 3 and VCR showed more potent activity with IR values of $53 \%$ at the MTDs compared with that of $\mathbf{2 9 b}$.

Consequently, compound (29b) was selected for further evaluation against various drug-resistant cell lines. ${ }^{19)}$ As shown in Table 4, compound (29b) did not show cross-resistance as indicated by the almost equal rates against all drugresistant cell lines, while all reference drugs drastically decreased the in vitro activity against each drug resistant cell. Compound (29b) possessed high activity against solid tumors that were insensitive to some chemotherapeutic drugs.

Physico-chemical properties of compound (29b) were

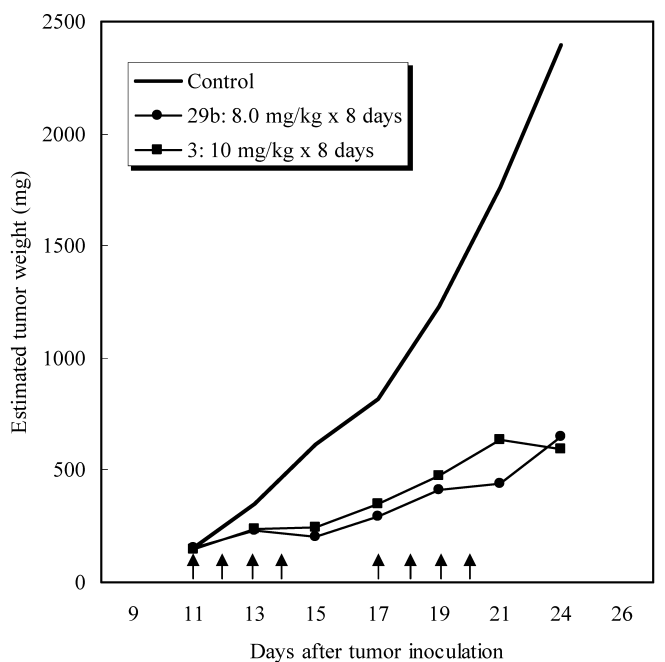

Fig. 3. Tumor Growth Inhibition Curves of $\mathbf{2 9 b}$ and $\mathbf{3}$ against PC-12

Human non-small cell lung cancer PC-12 block was inoculated s.c. into BALB/cAnNCrj-nu mice (day 0). Compounds $\mathbf{2 9 b}$ and $\mathbf{3}$ at the indicated doses were administered orally on days $11-14$ and $17-20$, consecutively.

compared with those of compounds (2-4) (Table 5). Water solubility of both monohalogenated and dihalogenated compounds $(\mathbf{2}-\mathbf{4})$ were low at $\mathrm{pH}=6.8$, whereas the appropriate amount could be dissolved at $\mathrm{pH}=1.1$ because of the existence of piperazine. Especially, the dihalogenated compounds $(3,4)$ showed poor water solubility compared with the monohalogenated compound (2). The logarithm of the distribution coefficient $(\operatorname{LogD})$ of compound $(\mathbf{2 9 b})$ in $n$-octanol/water system was 2.9 while those of the mono and dihalogenated compounds $(2-4)$ were more than 3.5 at $\mathrm{pH}=6.8$. Introduction of a cyano group on the phenyl ring improved water solubility. 
Table 5. Physico-chemical Properties of 1-trans-Propene Derivatives

\begin{tabular}{crrr}
\hline \hline & \multicolumn{2}{c}{ Water solubility $(\mu \mathrm{g} / \mathrm{ml})$} & \multirow{2}{*}{$\operatorname{LogD}^{a)}(\mathrm{pH}=6.8)$} \\
\cline { 2 - 3 } Compd. No. & $\mathrm{pH}=1.1$ & $\mathrm{pH}=6.8$ & \\
\hline $\mathbf{2}$ & 86.0 & 16.9 & $>3.7$ \\
$\mathbf{3}$ & 244.2 & 5.1 & $>3.6$ \\
$\mathbf{4}$ & 77.7 & 1.6 & $>3.5$ \\
$\mathbf{2 9 b}$ & 307.1 & 107.4 & 2.9 \\
\hline
\end{tabular}

a) The logarithm of the distribution coefficient $(\operatorname{LogD})$ of compounds in $n$ octanol/water system.

In conclusion, the study on structural modifications of moieties $\mathrm{A}, \mathrm{B}$, and $\mathrm{E}$ in this scaffold $\mathbf{1}$ has resulted in the discovery of the 3-chloropyridin-2-yl compound (9g) and the 3-fluoro-5-substituted phenyl derivatives $(\mathbf{2 9 b}, \mathbf{c}, \mathbf{e})$, which showed strong in vitro cytotoxic activity. Among them, compound (29b) displayed potent antitumor activity in mice without causing undesirable effects by means of both intraperitoneal injection and oral administration. The mechanism of action for the cytotoxic activity of this scaffold was reported to be inhibition of tubulin polymerization. ${ }^{20,21)}$ Therefore, the tubulin polymerization inhibitory activity of 29b was evaluated. As a result, compound (29b) displayed inhibition concentration values $\left(\mathrm{IC}_{50}\right)$ of $53 \mu \mathrm{M}$, suggesting that inhibition of tubulin polymerization contributes to expression of the activity. Further work to improve the activity and the mechanism of action in cells will be described elsewhere.

\section{Experimental}

Melting points were determined on a Yanaco MP-500D apparatus and are uncorrected. Infrared (IR) spectra were recorded on a JEOL JIR-5300 or Horiba FT-720 spectrometer. ${ }^{1} \mathrm{H}-\mathrm{NMR}$ spectra were recorded on a JEOL JNM-EX400 $(400 \mathrm{MHz})$ instrument, and the chemical shifts are given in $\delta$ values. Mass spectra (MS) were recorded on a JEOL JMS-HX110 or a JMSAX505W mass spectrometer. Elemental analyses were performed with a Perkin-Elmer Series II CHNS/O 2400 instrument. Column chromatography was performed with silica gel 60 F 254 (70-230 mesh) (Merck). Sodium sulfate was employed as a drying agent.

4-Acetyl-5-methyl-1-(2-pyridyl)pyrazole (6a) A mixture of pyridin-2ylhydrazine $(3.3 \mathrm{~g}, 30 \mathrm{mmol})$ and ethoxymethyleneacetylacetone ${ }^{8)}(4.7 \mathrm{~g}$, $30 \mathrm{mmol})$ in $\mathrm{EtOH}(40 \mathrm{ml})$ was stirred at $70^{\circ} \mathrm{C}$ for $1 \mathrm{~h}$. The reaction mixture was cooled, and the precipitate obtained was filtered to give $6 \mathrm{a}(4.6 \mathrm{~g}, 74 \%)$ as a pale yellow powder. Compounds $\mathbf{5 b}-\mathbf{k}$ were treated in the same manner as described above to give $\mathbf{6} \mathbf{b}-\mathbf{k}$, respectively.

6a: Yield $74 \%$, a pale yellow powder. ${ }^{1} \mathrm{H}-\mathrm{NMR}\left(\mathrm{CDCl}_{3}\right) \delta: 2.51(3 \mathrm{H}, \mathrm{s})$ $2.92(3 \mathrm{H}, \mathrm{s}), 7.32(1 \mathrm{H}, \mathrm{t}, J=5 \mathrm{~Hz}), 7.80(1 \mathrm{H}, \mathrm{d}, J=8 \mathrm{~Hz}), 7.88(1 \mathrm{H}, \mathrm{t}$, $J=8 \mathrm{~Hz}), 8.02(1 \mathrm{H}, \mathrm{s}), 8.53(1 \mathrm{H}, \mathrm{d}, J=5 \mathrm{~Hz})$.

6b: Yield $90 \%$, a pale yellow powder. ${ }^{1} \mathrm{H}-\mathrm{NMR}\left(\mathrm{CDCl}_{3}\right) \delta: 2.51(3 \mathrm{H}, \mathrm{s})$ $2.72(3 \mathrm{H}, \mathrm{s}), 7.46(2 \mathrm{H}, \mathrm{d}, J=6 \mathrm{~Hz}), 8.06(1 \mathrm{H}, \mathrm{s}), 8.78(2 \mathrm{H}, \mathrm{d}, J=6 \mathrm{~Hz})$.

6c: Yield $55 \%$, a colorless powder. ${ }^{1} \mathrm{H}-\mathrm{NMR}\left(\mathrm{CDCl}_{3}\right) \delta: 2.52(3 \mathrm{H}, \mathrm{s})$, $2.95(3 \mathrm{H}, \mathrm{s}), 8.06(1 \mathrm{H}, \mathrm{s}), 8.47(1 \mathrm{H}, \mathrm{dd}, J=3,2 \mathrm{~Hz}), 8.59(1 \mathrm{H}, \mathrm{d}, J=3 \mathrm{~Hz})$, $9.23(1 \mathrm{H}, \mathrm{d}, J=2 \mathrm{~Hz})$.

6d: Yield $64 \%$, a red amorphous solid. ${ }^{1} \mathrm{H}-\mathrm{NMR}\left(\mathrm{DMSO}-d_{6}\right) \delta: 2.51(3 \mathrm{H}$, s), $2.66(3 \mathrm{H}, \mathrm{s}), 7.77(1 \mathrm{H}, \mathrm{br} \mathrm{s}), 8.24(2 \mathrm{H}, \mathrm{br} \mathrm{s})$.

6e: Yield $82 \%$, a pale yellow powder. ${ }^{1} \mathrm{H}-\mathrm{NMR}\left(\mathrm{CDCl}_{3}\right) \delta$ : $2.52(3 \mathrm{H}, \mathrm{s})$, $3.18(3 \mathrm{H}, \mathrm{s}), 7.40(1 \mathrm{H}, \mathrm{t}, J=8 \mathrm{~Hz}), 7.50(1 \mathrm{H}, \mathrm{t}, J=8 \mathrm{~Hz}), 7.86(1 \mathrm{H}, \mathrm{d}$, $J=8 \mathrm{~Hz}), 7.96(1 \mathrm{H}, \mathrm{d}, J=8 \mathrm{~Hz}), 8.03(1 \mathrm{H}, \mathrm{s})$.

6f: Yield $63 \%$, a pale yellow powder. ${ }^{1} \mathrm{H}-\mathrm{NMR}\left(\mathrm{CDCl}_{3}\right) \delta: 2.53(3 \mathrm{H}, \mathrm{s})$ $3.10(3 \mathrm{H}, \mathrm{s}), 7.60(1 \mathrm{H}, \mathrm{t}, J=7 \mathrm{~Hz}), 7.77(1 \mathrm{H}, \mathrm{t}, J=8 \mathrm{~Hz}), 7.88(1 \mathrm{H}, \mathrm{d}$, $J=8 \mathrm{~Hz}), 8.02(1 \mathrm{H}, \mathrm{d}, J=9 \mathrm{~Hz}), 8.06(1 \mathrm{H}, \mathrm{s}), 8.07(1 \mathrm{H}, \mathrm{d}, J=6 \mathrm{~Hz}), 8.32$ $(1 \mathrm{H}, \mathrm{d}, J=7 \mathrm{~Hz})$.

6g: Yield $65 \%$, a pale yellow powder. ${ }^{1} \mathrm{H}-\mathrm{NMR}\left(\mathrm{CDCl}_{3}\right) \delta: 2.50(3 \mathrm{H}, \mathrm{s})$, $2.52(3 \mathrm{H}, \mathrm{s}), 7.47(1 \mathrm{H}, \mathrm{dd}, J=8,5 \mathrm{~Hz}), 7.97(1 \mathrm{H}, \mathrm{dd}, J=8,2 \mathrm{~Hz}), 8.08(1 \mathrm{H}$, s), $8.56(1 \mathrm{H}, \mathrm{dd}, J=5,2 \mathrm{~Hz})$.

6h: Yield $74 \%$, a pale yellow powder. ${ }^{1} \mathrm{H}-\mathrm{NMR}\left(\mathrm{CDCl}_{3}\right) \delta$ : $2.47(3 \mathrm{H}, \mathrm{s})$, $2.52(3 \mathrm{H}, \mathrm{s}), 7.37(1 \mathrm{H}, \mathrm{d}, J=5 \mathrm{~Hz}), 8.08(1 \mathrm{H}, \mathrm{s}), 8.70(1 \mathrm{H}, \mathrm{d}, J=5 \mathrm{~Hz}), 8.84$
$(1 \mathrm{H}, \mathrm{s})$.

6i: Yield $28 \%$, a pale yellow powder. ${ }^{1} \mathrm{H}-\mathrm{NMR}\left(\mathrm{CDCl}_{3}\right) \delta$ : $2.41(3 \mathrm{H}, \mathrm{s})$, $2.53(3 \mathrm{H}, \mathrm{s}), 8.14(1 \mathrm{H}, \mathrm{s}), 8.7-8.8(3 \mathrm{H}, \mathrm{m})$.

6j: Yield 64\%, a pale yellow powder. ${ }^{1} \mathrm{H}-\mathrm{NMR}\left(\mathrm{CDCl}_{3}\right) \delta: 2.52(3 \mathrm{H}, \mathrm{s})$, $2.97(3 \mathrm{H}, \mathrm{s}), 8.10(1 \mathrm{H}, \mathrm{s}), 8.79(2 \mathrm{H}, \mathrm{s})$.

3-[4-(3-Chlorophenyl)-1-piperazinyl]-1-[5-methyl-1-(2-pyridyl)-4-1Hpyrazolyl]-1-propanone (8a) Paraformaldehyde $(1.4 \mathrm{~g}, 46 \mathrm{mmol})$ and a solution of $1 \mathrm{~N} \mathrm{HCl} / \mathrm{EtOH}(11 \mathrm{ml})$ were added to a mixture of $\mathbf{6 a}(2.3 \mathrm{~g}$, $11 \mathrm{mmol})$ and $7 \mathbf{a}^{1,2)}(2.6 \mathrm{~g}, 11 \mathrm{mmol})$ in EtOH $(200 \mathrm{ml})$, and the mixture was heated to reflux for $2 \mathrm{~d}$. The mixture was diluted with $\mathrm{CHCl}_{3}$, successively washed with saturated aqueous $\mathrm{NaHCO}_{3}$ and brine, and then dried. Evaporation of the solvents afforded the crude mixture, which was chromatographed on a silica gel column $\left(\mathrm{CHCl}_{3} / \mathrm{MeOH}=50 / 1\right)$ to give $8 \mathbf{a}(2.3 \mathrm{~g}, 50 \%)$ as a yellow amorphous solid. Compounds $\mathbf{6} \mathbf{b}-\mathbf{k}$ and $7 \mathbf{a}-\mathbf{c}$ were treated in the same manner as described above to give $\mathbf{8 b}-\mathbf{k}$, respectively. The physical data for these compounds and yields are shown in Table 6.

3-[4-(3-Chlorophenyl)-1-piperazinyl]-1-[5-methyl-1-(2-pyridyl)-4-1Hpyrazolyl]-1-trans-propene Hydrochloride (9a) Sodium borohydride $(0.55 \mathrm{~g}, 15 \mathrm{mmol})$ was added in small portions to a solution of $8 \mathrm{a}(1.3 \mathrm{mg}$, $2.9 \mathrm{mmol})$ in anhydrous $\mathrm{EtOH}(70 \mathrm{ml})$ and THF $(70 \mathrm{ml})$ at $0{ }^{\circ} \mathrm{C}$, and the reaction mixture was stirred at room temperature for $2 \mathrm{~h}$. The reaction mixture was quenched with a solution of $1 \mathrm{~N} \mathrm{HCl} / \mathrm{EtOH}$. The mixture was diluted with $\mathrm{CHCl}_{3}$, successively washed with saturated aqueous $\mathrm{NaHCO}_{3}$ and brine, and dried. Evaporation of the solvents afforded the corresponding secondary alcohol. Next, $p$ - TsOH $\cdot \mathrm{H}_{2} \mathrm{O}(0.83 \mathrm{~g}, 4.4 \mathrm{mmol})$ was added to a solution of the above product in anhydrous 1,4-dioxane $(50 \mathrm{ml})$ and THF $(50 \mathrm{ml})$, and the mixture was heated to reflux for $3.5 \mathrm{~h}$. The reaction mixture was diluted with $\mathrm{CHCl}_{3}$, successively washed with saturated aqueous $\mathrm{NaHCO}_{3}$ and brine, and dried. After removal of the solvents, the crude mixture was chromatographed on a silica gel column $\left(\mathrm{CHCl}_{3} / \mathrm{MeOH}=50 / 1\right)$ to afford the propene. An appropriate volume of a solution of $1 \mathrm{~N} \mathrm{HCl} / \mathrm{EtOH}$ was added to a solution of the propene in a small amount of $\mathrm{EtOH}$, and the solvent was removed. The residue was recrystallized from EtOH to give 9a $(0.89 \mathrm{~g}, 70 \%)$ as a pale yellow powder. Compounds $\mathbf{8 b}-\mathbf{k}$ were treated in the same manner as described above to give $\mathbf{9 b}-\mathbf{k}$, respectively. The physical data for these compounds and yields are shown in Table 7.

4-Iodo-1-(2-pyrimidinyl)pyrazole (11) Periodic acid (2.1 g), iodine $(4.5 \mathrm{~g})$, water $(10 \mathrm{ml})$, and sulfuric acid $(1.5 \mathrm{ml})$ were successively added to a solution of $10^{11)}(6.2 \mathrm{~g}, 42 \mathrm{mmol})$ in acetic acid $(51 \mathrm{ml})$, and the mixture was stirred at $65^{\circ} \mathrm{C}$ for $2.5 \mathrm{~h}$. The solvents were evaporated in vacuo, and water $(90 \mathrm{ml})$ and $\mathrm{NaHCO}_{3}(5.2 \mathrm{~g})$ were added to the residue. The resulting precipitates were collected by filtration to give $\mathbf{1 1}(8.4 \mathrm{~g}, 73 \%)$ as a pale yellow solid: ${ }^{1} \mathrm{H}-\mathrm{NMR}\left(\mathrm{CDCl}_{3}\right) \delta: 7.25(1 \mathrm{H}, \mathrm{t}, J=5 \mathrm{~Hz}), 7.83(1 \mathrm{H}, \mathrm{s}), 8.68(1 \mathrm{H}, \mathrm{s})$, $8.76(2 \mathrm{H}, \mathrm{d}, J=5 \mathrm{~Hz})$.

1-(2-Pyrimidinyl)-4-vinylpyrazole (12) 2,6-Di-tert-butyl-4-methylphenol $(50 \mathrm{mg})$ was added to a mixture of $\mathbf{1 1}(2.0 \mathrm{~g}, 7.5 \mathrm{mmol})$, vinyltributylstannum $(2.4 \mathrm{ml}, 8.0 \mathrm{mmol})$, lithium chloride $(1.0 \mathrm{~g}, 23 \mathrm{mmol})$, and tetrakis(triphenylphosphine)palladium $(0)(0.18 \mathrm{~g}, 0.16 \mathrm{mmol})$ in 1,4-dioxane $(38 \mathrm{ml})$, and the mixture was heated to reflux for $4 \mathrm{~h} .10 \%$ Aqueous KF $(20 \mathrm{ml})$ was added to the reaction mixture, and the mixture was stirred for $8 \mathrm{~h}$ at room temperature. The resulting precipitates were removed by filtration. The filtrate was diluted with AcOEt, and the solution was successively washed with water and brine, and then dried. Filtration and evaporation of the solvent afforded the crude mixture, which was chromatographed on a silica gel column $(\mathrm{AcOEt} / \mathrm{hexane}=3 / 1)$ to give $\mathbf{1 2}(0.87 \mathrm{~g}, 68 \%)$ as a pale brown solid: ${ }^{1} \mathrm{H}-\mathrm{NMR}\left(\mathrm{CDCl}_{3}\right) \delta: 5.24(1 \mathrm{H}, \mathrm{dd}, J=11,1 \mathrm{~Hz}), 5.64(1 \mathrm{H}, \mathrm{dd}$, $J=18,1 \mathrm{~Hz}), 6.61(1 \mathrm{H}, \mathrm{dd}, J=18,11 \mathrm{~Hz}), 7.20(1 \mathrm{H}, \mathrm{t}, J=5 \mathrm{~Hz}), 7.94(1 \mathrm{H}, \mathrm{s})$, $8.55(1 \mathrm{H}, \mathrm{s}), 8.74(2 \mathrm{H}, \mathrm{d}, J=5 \mathrm{~Hz})$.

4-Acetyl-1-(2-pyrimidinyl)pyrazole (15a) Compound $12 \quad(0.50 \mathrm{~g}$, $2.9 \mathrm{mmol}$ ) was added to $35 \%$ aqueous sulfuric acid $(15 \mathrm{ml})$, and the mixture was stirred for $24 \mathrm{~h}$ at room temperature. The reaction mixture was diluted with ice-water and alkalized with $\mathrm{NaHCO}_{3}$, and the whole was extracted with $\mathrm{CHCl}_{3} / \mathrm{MeOH}(9 / 1)$. The organic layer was washed with brine and dried. After filtration and evaporation of the solvents, the crude mixture was chromatographed on a silica gel column $(\mathrm{AcOEt} / \mathrm{hexane}=3 / 1)$ to afford the corresponding alcohol $(0.12 \mathrm{~g}, 22 \%)$ : ${ }^{1} \mathrm{H}-\mathrm{NMR}\left(\mathrm{CDCl}_{3}\right) \delta: 1.58(3 \mathrm{H}, \mathrm{d}$, $J=7 \mathrm{~Hz}), 5.00(1 \mathrm{H}, \mathrm{q}, J=7 \mathrm{~Hz}), 7.21(1 \mathrm{H}, \mathrm{t}, J=5 \mathrm{~Hz}), 8.53(1 \mathrm{H}, \mathrm{s}), 7.93$ $(1 \mathrm{H}, \mathrm{s}), 8.74(2 \mathrm{H}, \mathrm{d}, J=5 \mathrm{~Hz})$.

The mixture of the above alcohol $(0.12 \mathrm{~g}, 0.64 \mathrm{mmol})$ and manganese (IV) oxide $(0.80 \mathrm{~g}, 9.2 \mathrm{mmol})$ was stirred for $12 \mathrm{~h}$ at room temperature. The reaction mixture was diluted with AcOEt, and the whole was filtered through a Celite pad. Removal of the solvent afforded 15a $(0.11 \mathrm{~g}, 92 \%)$ as a white solid: ${ }^{1} \mathrm{H}-\mathrm{NMR}\left(\mathrm{CDCl}_{3}\right) \delta: 2.54(3 \mathrm{H}, \mathrm{s}), 7.33(1 \mathrm{H}, \mathrm{t}, J=5 \mathrm{~Hz}), 8.22(1 \mathrm{H}, \mathrm{s})$, $8.81(2 \mathrm{H}, \mathrm{d}, J=5 \mathrm{~Hz}), 9.09(1 \mathrm{H}, \mathrm{s})$. 
Table 6. Physical Data for Propanone Derivatives

\begin{tabular}{|c|c|c|}
\hline $\begin{array}{l}\text { Compd. } \\
\text { No. }\end{array}$ & $\begin{array}{l}\text { Yield } \\
(\%)\end{array}$ & ${ }^{1} \mathrm{H}-\mathrm{NMR}\left(\mathrm{CDCl}_{3}\right) \delta$ \\
\hline $8 a$ & 50 & $\begin{array}{l}2.84(3 \mathrm{H}, \mathrm{s}), 3.1-3.3(4 \mathrm{H}, \mathrm{m}), 4-3.6(4 \mathrm{H}, \mathrm{m}), 3.6-3.7(2 \mathrm{H}, \mathrm{m}), 3.9-4.0(2 \mathrm{H}, \mathrm{m}), 6.88(1 \mathrm{H}, \mathrm{d}, J=8 \mathrm{~Hz}), 6.98(1 \mathrm{H}, \mathrm{d}, J=8 \mathrm{~Hz}), \\
7.08(1 \mathrm{H}, \mathrm{s}), 7.27(1 \mathrm{H}, \mathrm{t}, J=8 \mathrm{~Hz}), 7.51(1 \mathrm{H}, \mathrm{t}, J=5 \mathrm{~Hz}), 8.4(1 \mathrm{H}, \mathrm{d}, J=8 \mathrm{~Hz}), 8.08(1 \mathrm{H}, \mathrm{t}, J=8 \mathrm{~Hz}), 8.40(1 \mathrm{H}, \mathrm{s}), 8.58(1 \mathrm{H}, \mathrm{d}, J=5 \mathrm{~Hz})\end{array}$ \\
\hline $8 \mathbf{b}$ & 31 & $\begin{array}{l}2.73(3 \mathrm{H}, \mathrm{s}), 3.1-3.3(4 \mathrm{H}, \mathrm{m}), 3.5-4.0(8 \mathrm{H}, \mathrm{m}), 6.88(1 \mathrm{H}, \mathrm{dd}, J=8,2 \mathrm{~Hz}), 6.99(1 \mathrm{H}, \mathrm{dd}, J=8,2 \mathrm{~Hz}), 7.08(1 \mathrm{H}, \mathrm{s}), 7.27(1 \mathrm{H}, \mathrm{t}, J=8 \mathrm{~Hz}), \\
7.88(2 \mathrm{H}, \mathrm{d}, J=6 \mathrm{~Hz}), 8.52(1 \mathrm{H}, \mathrm{s}), 8.87(2 \mathrm{H}, \mathrm{d}, J=6 \mathrm{~Hz})\end{array}$ \\
\hline $8 c$ & 79 & $\begin{array}{l}2.85(3 \mathrm{H}, \mathrm{s}), 3.1-3.4(6 \mathrm{H}, \mathrm{m}), 3.5-3.7(4 \mathrm{H}, \mathrm{m}), 3.8-4.0(2 \mathrm{H}, \mathrm{m}), 6.87(1 \mathrm{H}, \mathrm{dd}, J=8,2 \mathrm{~Hz}), 6.98(1 \mathrm{H}, \mathrm{dd}, J=8,2 \mathrm{~Hz}) \\
7.08(1 \mathrm{H}, \mathrm{t}, J=2 \mathrm{~Hz}), 7.27(1 \mathrm{H}, \mathrm{dt}, J=8,2 \mathrm{~Hz}), 8.50(1 \mathrm{H}, \mathrm{s}), 8.66(1 \mathrm{H}, \mathrm{dd}, J=3,2 \mathrm{~Hz}), 8.76(1 \mathrm{H}, \mathrm{d}, J=3 \mathrm{~Hz}), 9.16(2 \mathrm{H}, \mathrm{d}, J=2 \mathrm{~Hz})\end{array}$ \\
\hline $8 d$ & 14 & $\begin{array}{l}2.53(3 \mathrm{H}, \mathrm{s}), 3.0-3.2(4 \mathrm{H}, \mathrm{m}), 3.2-3.4(4 \mathrm{H}, \mathrm{m}), 3.5-3.6(2 \mathrm{H}, \mathrm{m}), 3.6-3.8(2 \mathrm{H}, \mathrm{m}), 6.88(2 \mathrm{H}, \mathrm{d}, J=8 \mathrm{~Hz}), 6.98(2 \mathrm{H}, \mathrm{d}, J=8 \mathrm{~Hz}) \\
7.08(1 \mathrm{H}, \mathrm{s}), 7.27(1 \mathrm{H}, \mathrm{t}, J=8 \mathrm{~Hz}), 7.75(1 \mathrm{H}, \mathrm{d}, J=4 \mathrm{~Hz}), 8.25(1 \mathrm{H}, \mathrm{d}, J=4 \mathrm{~Hz})\end{array}$ \\
\hline $8 e$ & 37 & $\begin{array}{l}2.67(4 \mathrm{H}, \mathrm{t}, J=5 \mathrm{~Hz}), 2.89(2 \mathrm{H}, \mathrm{t}, J=7 \mathrm{~Hz}), 3.08(2 \mathrm{H}, \mathrm{t}, J=7 \mathrm{~Hz}), 3.19(3 \mathrm{H}, \mathrm{s}), 3.22(4 \mathrm{H}, \mathrm{t}, J=5 \mathrm{~Hz}), 6.80(2 \mathrm{H}, \mathrm{dt}, J=8,2 \mathrm{~Hz}) \\
6.88(1 \mathrm{H}, \mathrm{t}, J=2 \mathrm{~Hz}), 7.16(1 \mathrm{H}, \mathrm{t}, J=8 \mathrm{~Hz}), 7.41(1 \mathrm{H}, \mathrm{t}, J=8 \mathrm{~Hz}), 7.51(1 \mathrm{H}, \mathrm{t}, J=8 \mathrm{~Hz}), 8.87(1 \mathrm{H}, \mathrm{d}, J=8 \mathrm{~Hz}), 7.96(1 \mathrm{H}, \mathrm{d}, J=8 \mathrm{~Hz}), \\
8.09(1 \mathrm{H}, \mathrm{s})\end{array}$ \\
\hline $8 f$ & 49 & $\begin{array}{l}3.04(3 \mathrm{H}, \mathrm{s}), 3.1-3.3(4 \mathrm{H}, \mathrm{m}), 3.5-3.6(4 \mathrm{H}, \mathrm{m}), 3.6-3.7(2 \mathrm{H}, \mathrm{m}), 3.9-4.0(2 \mathrm{H}, \mathrm{m}), 6.88(1 \mathrm{H}, \mathrm{d}, J=8 \mathrm{~Hz}), 7.00(1 \mathrm{H}, \mathrm{d}, J=8 \mathrm{~Hz}) \\
7.09(1 \mathrm{H}, \mathrm{s}), 7.27(1 \mathrm{H}, \mathrm{t}, J=8 \mathrm{~Hz}), 7.70(1 \mathrm{H}, \mathrm{t}, J=8 \mathrm{~Hz}), 7.87(1 \mathrm{H}, \mathrm{t}, J=8 \mathrm{~Hz}), 8.04(1 \mathrm{H}, \mathrm{d}, J=8 \mathrm{~Hz}), 8.06(1 \mathrm{H}, \mathrm{d}, J=9 \mathrm{~Hz}) \\
8.10(1 \mathrm{H}, \mathrm{d}, J=8 \mathrm{~Hz}), 8.49(1 \mathrm{H}, \mathrm{s}), 8.64(1 \mathrm{H}, \mathrm{d}, J=9 \mathrm{~Hz})\end{array}$ \\
\hline $8 g$ & 53 & $\begin{array}{l}2.51(3 \mathrm{H}, \mathrm{s}), 2.66(4 \mathrm{H}, \mathrm{t}, J=5 \mathrm{~Hz}), 2.89(2 \mathrm{H}, \mathrm{t}, J=7 \mathrm{~Hz}), 3.08(2 \mathrm{H}, \mathrm{t}, J=7 \mathrm{~Hz}), 3.21(4 \mathrm{H}, \mathrm{t}, J=5 \mathrm{~Hz}), 6.3-6.4(1 \mathrm{H}, \mathrm{m}), 6.4-6.5(2 \mathrm{H}, \mathrm{m}), \\
7.48(1 \mathrm{H}, \mathrm{dd}, J=8,5 \mathrm{~Hz}), 7.97(1 \mathrm{H}, \mathrm{dd}, J=8,2 \mathrm{~Hz}), 8.12(1 \mathrm{H}, \mathrm{s}), 8.56(1 \mathrm{H}, \mathrm{dd}, J=5,2 \mathrm{~Hz})\end{array}$ \\
\hline $8 \mathbf{h}$ & 36 & $\begin{array}{l}2.47(3 \mathrm{H}, \mathrm{s}), 2.67(4 \mathrm{H}, \mathrm{t}, J=5 \mathrm{~Hz}), 2.90(2 \mathrm{H}, \mathrm{t}, J=7 \mathrm{~Hz}), 3.09(2 \mathrm{H}, \mathrm{t}, J=7 \mathrm{~Hz}), 3.22(4 \mathrm{H}, \mathrm{t}, J=5 \mathrm{~Hz}), 6.25(1 \mathrm{H}, \mathrm{tt}, J=9,2 \mathrm{~Hz}) \\
6.36(2 \mathrm{H}, \mathrm{dd}, J=9,2 \mathrm{~Hz}), 7.37(1 \mathrm{H}, \mathrm{d}, J=5 \mathrm{~Hz}), 8.13(1 \mathrm{H}, \mathrm{s}), 8.70(1 \mathrm{H}, \mathrm{d}, J=5 \mathrm{~Hz}), 8.84(1 \mathrm{H}, \mathrm{s})\end{array}$ \\
\hline $8 \mathbf{i}$ & 24 & $\begin{array}{l}2.37(3 \mathrm{H}, \mathrm{s}), 3.2-3.3(4 \mathrm{H}, \mathrm{m}), 3.5-3.6(4 \mathrm{H}, \mathrm{m}), 3.6-3.7(2 \mathrm{H}, \mathrm{m}), 3.9-4.1(2 \mathrm{H}, \mathrm{m}), 6.5-6.6(1 \mathrm{H}, \mathrm{m}), 6.7-6.8(2 \mathrm{H}, \mathrm{m}), 8.51(1 \mathrm{H}, \mathrm{s}), \\
8.99(2 \mathrm{H}, \mathrm{s})\end{array}$ \\
\hline $8 \mathbf{j}$ & 24 & $\begin{array}{l}2.84(3 \mathrm{H}, \mathrm{s}), 3.1-3.3(4 \mathrm{H}, \mathrm{m}), 3.3-3.6(4 \mathrm{H}, \mathrm{m}), 3.6-3.7(2 \mathrm{H}, \mathrm{m}), 3.9-4.1(2 \mathrm{H}, \mathrm{m}), 6.5-6.6(1 \mathrm{H}, \mathrm{m}), 6.74(2 \mathrm{H}, \mathrm{d}, J=9 \mathrm{~Hz}) \\
7.89(1 \mathrm{H}, \mathrm{d}, J=9 \mathrm{~Hz}), 8.19(1 \mathrm{H}, \mathrm{dd}, J=9,3 \mathrm{~Hz}), 8.42(1 \mathrm{H}, \mathrm{s}), 8.63(1 \mathrm{H}, \mathrm{d}, J=3 \mathrm{~Hz})\end{array}$ \\
\hline $8 \mathbf{k}$ & 62 & $\begin{array}{l}2.54(3 \mathrm{H}, \mathrm{s}), 3.1-3.3(4 \mathrm{H}, \mathrm{m}), 3.4-3.5(4 \mathrm{H}, \mathrm{m}), 3.5-3.7(2 \mathrm{H}, \mathrm{m}), 3.9-4.1(2 \mathrm{H}, \mathrm{m}), 6.96(1 \mathrm{H}, \mathrm{s}), 7.08(2 \mathrm{H}, \mathrm{s}), 7.5-7.6(5 \mathrm{H}, \mathrm{m}), \\
8.36(1 \mathrm{H}, \mathrm{s})\end{array}$ \\
\hline $16 \mathrm{a}$ & 58 & $\begin{array}{l}2.67(4 \mathrm{H}, \mathrm{t}, J=5 \mathrm{~Hz}), 2.90(2 \mathrm{H}, \mathrm{t}, J=7 \mathrm{~Hz}), 3.10(2 \mathrm{H}, \mathrm{t}, J=7 \mathrm{~Hz}), 3.21(4 \mathrm{H}, \mathrm{t}, J=5 \mathrm{~Hz}), 6.7-6.8(2 \mathrm{H}, \mathrm{m}), 6.87(1 \mathrm{H}, \mathrm{t}, J=2 \mathrm{~Hz}) \\
7.16(1 \mathrm{H}, \mathrm{t}, J=8 \mathrm{~Hz}), 7.33(1 \mathrm{H}, \mathrm{t}, J=5 \mathrm{~Hz}), 8.24(1 \mathrm{H}, \mathrm{s}), 8.81(2 \mathrm{H}, \mathrm{d}, J=5 \mathrm{~Hz}), 9.13(1 \mathrm{H}, \mathrm{s})\end{array}$ \\
\hline $16 \mathrm{~b}$ & 36 & $\begin{array}{l}2.63(3 \mathrm{H}, \mathrm{s}), 2.67(4 \mathrm{H}, \mathrm{t}, J=5 \mathrm{~Hz}), 2.89(2 \mathrm{H}, \mathrm{t}, J=7 \mathrm{~Hz}), 3.08(2 \mathrm{H}, \mathrm{t}, J=7 \mathrm{~Hz}), 3.21(4 \mathrm{H}, \mathrm{t}, J=5 \mathrm{~Hz}), 6.79(2 \mathrm{H}, \mathrm{dt}, J=8,2 \mathrm{~Hz}) \\
6.87(1 \mathrm{H}, \mathrm{t}, J=2 \mathrm{~Hz}), 7.16(1 \mathrm{H}, \mathrm{t}, J=8 \mathrm{~Hz}), 7.28(1 \mathrm{H}, \mathrm{t}, J=5 \mathrm{~Hz}), 8.78(2 \mathrm{H}, \mathrm{d}, J=5 \mathrm{~Hz}), 9.08(1 \mathrm{H}, \mathrm{s})\end{array}$ \\
\hline $16 \mathrm{c}$ & 32 & $\begin{array}{l}2.58(2 \mathrm{H}, \mathrm{t}, J=5 \mathrm{~Hz}), 2.61(3 \mathrm{H}, \mathrm{s}), 2.66(2 \mathrm{H}, \mathrm{t}, J=5 \mathrm{~Hz}), 2.8-3.0(1 \mathrm{H}, \mathrm{m}), 2.91(3 \mathrm{H}, \mathrm{s}), 3.06(1 \mathrm{H}, \mathrm{t}, J=7 \mathrm{~Hz}), 3.1-3.3(4 \mathrm{H}, \mathrm{m}) \\
6.78(1 \mathrm{H}, \mathrm{d}, J=8 \mathrm{~Hz}), 6.81(1 \mathrm{H}, \mathrm{d}, J=8 \mathrm{~Hz}), 6.87(1 \mathrm{H}, \mathrm{s}), 7.16(1 \mathrm{H}, \mathrm{t}, J=8 \mathrm{~Hz}), 7.30(1 \mathrm{H}, \mathrm{t}, J=5 \mathrm{~Hz}), 8.84(2 \mathrm{H}, \mathrm{d}, J=5 \mathrm{~Hz})\end{array}$ \\
\hline $16 d$ & 48 & $\begin{array}{l}2.88(3 \mathrm{H}, \mathrm{s}), 3.2-3.3(4 \mathrm{H}, \mathrm{t}, J=5 \mathrm{~Hz}), 3.4-3.5(4 \mathrm{H}, \mathrm{m}), 3.6-3.7(2 \mathrm{H}, \mathrm{m}), 4.0-4.1(2 \mathrm{H}, \mathrm{m}), 6.85(1 \mathrm{H}, \mathrm{d}, J=3 \mathrm{~Hz}), 6.94(1 \mathrm{H}, \mathrm{s}) \\
7.06(2 \mathrm{H}, \mathrm{s}), 7.52(1 \mathrm{H}, \mathrm{t}, J=5 \mathrm{~Hz}), 7.60(1 \mathrm{H}, \mathrm{d}, J=3 \mathrm{~Hz}), 8.91(2 \mathrm{H}, \mathrm{d}, J=5 \mathrm{~Hz})\end{array}$ \\
\hline 28a & 26 & $\begin{array}{l}2.83(3 \mathrm{H}, \mathrm{s}), 3.1-3.2(4 \mathrm{H}, \mathrm{m}), 3.5-3.6(4 \mathrm{H}, \mathrm{m}), 3.6-3.7(2 \mathrm{H}, \mathrm{m}), 3.9-4.0(2 \mathrm{H}, \mathrm{m}), 6.91(1 \mathrm{H}, \mathrm{d}, J=12 \mathrm{~Hz}), 7.02(1 \mathrm{H}, \mathrm{d}, J=8 \mathrm{~Hz}) \\
7.1-7.2(1 \mathrm{H}, \mathrm{m}), 7.66(1 \mathrm{H}, \mathrm{t}, J=5 \mathrm{~Hz}), 8.41(1 \mathrm{H}, \mathrm{s}), 9.00(2 \mathrm{H}, \mathrm{d}, J=5 \mathrm{~Hz}), 10.1-10.2(1 \mathrm{H}, \mathrm{m})\end{array}$ \\
\hline $28 b$ & 20 & $\begin{array}{l}2.83(3 \mathrm{H}, \mathrm{s}), 3.1-3.3(4 \mathrm{H}, \mathrm{m}), 3.4-3.6(4 \mathrm{H}, \mathrm{m}), 3.65(2 \mathrm{H}, \mathrm{d}, J=11 \mathrm{~Hz}), 4.07(2 \mathrm{H}, \mathrm{d}, J=13 \mathrm{~Hz}), 7.1-7.2(1 \mathrm{H}, \mathrm{m}) \\
7.26(1 \mathrm{H}, \mathrm{dt}, J=13,2 \mathrm{~Hz}), 7.3-7.4(1 \mathrm{H}, \mathrm{m}), 7.66(1 \mathrm{H}, \mathrm{t}, J=5 \mathrm{~Hz}), 8.42(1 \mathrm{H}, \mathrm{s}), 9.00(2 \mathrm{H}, \mathrm{d}, J=5 \mathrm{~Hz}), 10.7-10.8(1 \mathrm{H}, \mathrm{m})\end{array}$ \\
\hline $28 c$ & 32 & $\begin{array}{l}2.5-2.6(4 \mathrm{H}, \mathrm{m}), 2.99(3 \mathrm{H}, \mathrm{s}), 3.0-3.2(2 \mathrm{H}, \mathrm{t}, J=7 \mathrm{~Hz}), 3.5-3.8(4 \mathrm{H}, \mathrm{m}), 6.55(1 \mathrm{H}, \mathrm{dt}, J=9,2 \mathrm{~Hz}), 6.8-6.9(2 \mathrm{H}, \mathrm{m}) \\
7.39(1 \mathrm{H}, \mathrm{t}, J=5 \mathrm{~Hz}), 8.32(1 \mathrm{H}, \mathrm{s}), 8.88(2 \mathrm{H}, \mathrm{d}, J=5 \mathrm{~Hz})\end{array}$ \\
\hline 28d & 30 & $\begin{array}{l}2.6-2.7(4 \mathrm{H}, \mathrm{m}), 2.89(2 \mathrm{H}, \mathrm{t}, J=7 \mathrm{~Hz}), 3.00(3 \mathrm{H}, \mathrm{s}), 3.09(2 \mathrm{H}, \mathrm{t}, J=7 \mathrm{~Hz}), 3.2-3.3(4 \mathrm{H}, \mathrm{m}), 6.7-6.8(1 \mathrm{H}, \mathrm{m}), 6.8-6.9(1 \mathrm{H}, \mathrm{m}) \\
6.88(1 \mathrm{H}, \mathrm{s}), 7.35(1 \mathrm{H}, \mathrm{t}, J=5 \mathrm{~Hz}), 8.15(1 \mathrm{H}, \mathrm{s}), 8.86(2 \mathrm{H}, \mathrm{d}, J=5 \mathrm{~Hz})\end{array}$ \\
\hline $28 \mathrm{e}$ & 32 & $\begin{array}{l}2.6-2.6(4 \mathrm{H}, \mathrm{m}), 2.88(2 \mathrm{H}, \mathrm{t}, J=7 \mathrm{~Hz}), 3.00(3 \mathrm{H}, \mathrm{s}), 3.08(2 \mathrm{H}, \mathrm{t}, J=7 \mathrm{~Hz}), 3.2-3.3(2 \mathrm{H}, \mathrm{m}), 6.46(1 \mathrm{H}, \mathrm{dt}, J=12,2 \mathrm{~Hz}) \\
6.53(1 \mathrm{H}, \mathrm{dt}, J=8,2 \mathrm{~Hz}), 6.64(1 \mathrm{H}, \mathrm{s}), 7.35(1 \mathrm{H}, \mathrm{t}, J=5 \mathrm{~Hz}), 8.14(1 \mathrm{H}, \mathrm{s}), 8.86(2 \mathrm{H}, \mathrm{d}, J=5 \mathrm{~Hz})\end{array}$ \\
\hline
\end{tabular}

4-Acetyl-3-methyl-1-(2-pyrimidinyl)pyrazole (15b) The mixture of $\mathbf{1 3}^{1,2)}(0.40 \mathrm{~g}, 2.0 \mathrm{mmol})$, diethyl carbonate $(0.40 \mathrm{ml})$, and $\mathrm{NaH}(0.16 \mathrm{~g}$ of $60 \%$ in mineral oil, $4.0 \mathrm{mmol})$ in toluene $(180 \mathrm{ml})$ was heated to reflux for $3 \mathrm{~h}$. The reaction mixture was poured into $10 \%$ hydrochloric acid, and the whole was extracted with AcOEt. The organic layer was washed with brine and dried. After filtration and evaporation of the solvents, the residue was recrystallized from ether to give $\mathbf{1 5 b}(0.31 \mathrm{~g}, 78 \%)$ as a colorless powder: ${ }^{1} \mathrm{H}-$ $\operatorname{NMR}\left(\mathrm{CDCl}_{3}\right) \delta: 2.52(3 \mathrm{H}, \mathrm{s}), 2.63(3 \mathrm{H}, \mathrm{s}), 7.28(1 \mathrm{H}, \mathrm{t}, J=5 \mathrm{~Hz}), 8.78(2 \mathrm{H}$ d, $J=5 \mathrm{~Hz}), 9.02(1 \mathrm{H}, \mathrm{s})$.

3-Acetyl-2-methyl-1-(2-pyrimidinyl)pyrrole (15d) Compound $\mathbf{1 4}^{14,15}$ $(0.92 \mathrm{~g}, 7.5 \mathrm{mmol})$ was added to a suspension of $\mathrm{KOH}(2.0 \mathrm{~g}, 30 \mathrm{mmol})$ in DMSO $(15 \mathrm{ml})$, and the reaction mixture was stirred at room temperature for $1 \mathrm{~h}$. 2-Chloropyrimidine $(1.0 \mathrm{~g}, 9.0 \mathrm{mmol})$ was added to the above reaction mixture, and the mixture was stirred for $20 \mathrm{~h}$ at room temperature. The reaction mixture was diluted with ice-water and the whole was extracted with AcOEt. The organic layer was washed with brine and dried. After filtration and evaporation of the solvents, the crude mixture was chromatographed on a silica gel column (hexane/AcOEt $=2 / 1)$ to afford $15 \mathbf{d}(1.2 \mathrm{~g}, 80 \%)$ as a colorless powder: ${ }^{1} \mathrm{H}-\mathrm{NMR}\left(\mathrm{CDCl}_{3}\right) \delta: 2.47(3 \mathrm{H}, \mathrm{s}), 2.96(3 \mathrm{H}, \mathrm{s}), 6.62(1 \mathrm{H}, \mathrm{d}$, $J=3 \mathrm{~Hz}), 7.20(1 \mathrm{H}, \mathrm{t}, J=5 \mathrm{~Hz}), 7.58(1 \mathrm{H}, \mathrm{d}, J=3 \mathrm{~Hz}), 8.73(2 \mathrm{H}, \mathrm{d}, J=5 \mathrm{~Hz})$.

3-[4-(3-Chlorophenyl)-1-piperazinyl]-1-[1-(2-pyrimidinyl)-4-1 H-pyrazolyl]-1-propanone (16a) Mannich reaction of $16 \mathbf{a}-\mathbf{d}$ from $15 \mathbf{a}-\mathbf{d}$ with $7 \mathbf{a}, \mathbf{c}$ was performed as described for the synthesis of $\mathbf{8 a}$. The physical data for $\mathbf{1 6 a}-\mathbf{d}$ are shown in Table 6.
3-[4-(3-Chlorophenyl)-1-piperazinyl]-1-[1-(2-pyrimidinyl)-4-1 H-pyrazolyl]-1-propene Hydrochloride (17a) Synthesis of 17a-d from 16a-d was performed as described for the synthesis of 9a. The physical data for 17a- $\mathbf{d}$ are shown in Table 7.

4-Ethoxycarbonyl-5-methyl-1-(2-pyrimidinyl)imidazole (19) The mixture of ethyl 4-methyl-5-imidazolecarboxylate $(\mathbf{1 8}, 20 \mathrm{~g}, 0.13 \mathrm{mmol})$, $\mathrm{K}_{2} \mathrm{CO}_{3}(18 \mathrm{~g}, 0.13 \mathrm{~mol})$, and 2-chloropyrimidine $(15 \mathrm{~g}, 0.13 \mathrm{mmol})$ in DMF $(132 \mathrm{ml})$ was stirred at $100^{\circ} \mathrm{C}$ for $6 \mathrm{~h}$. The reaction mixture was filtered through a Celite pad, and the filtrate was evaporated to afford the crude mixture, which was chromatographed on a silica gel column $\left(\mathrm{CHCl}_{3} / \mathrm{MeOH}=98 / 2\right)$ to give $19(22 \mathrm{~g}, 73 \%)$ as a brown amorphous solid: ${ }^{1} \mathrm{H}-\mathrm{NMR}\left(\mathrm{CDCl}_{3}\right) \delta: 1.43(3 \mathrm{H}, \mathrm{t}, J=7 \mathrm{~Hz}), 2.93(3 \mathrm{H}, \mathrm{s}), 4.41(2 \mathrm{H}, \mathrm{q}$, $J=7 \mathrm{~Hz}), 7.31(1 \mathrm{H}, \mathrm{t}, J=5 \mathrm{~Hz}), 8.50(1 \mathrm{H}, \mathrm{s}), 8.77(2 \mathrm{H}, \mathrm{d}, J=5 \mathrm{~Hz})$.

4-Formyl-5-methyl-1-(2-pyrimidinyl)imidazole (20) A solution of DIBAL ( $31 \mathrm{ml}$ of a $1.0 \mathrm{M}$ solution in hexane, $31 \mathrm{mmol}$ ) was added dropwise to a solution of $19(4.7 \mathrm{~g}, 20 \mathrm{mmol})$ in anhydrous $\mathrm{CH}_{2} \mathrm{Cl}_{2}(50 \mathrm{ml})$ and THF $(50 \mathrm{ml})$ at $-78^{\circ} \mathrm{C}$, and the mixture was stirred for $2.5 \mathrm{~h}$ at $-78^{\circ} \mathrm{C}$. The reaction mixture was poured into $1 \mathrm{~N}$ aqueous hydrochloric acid, and the whole was extracted with $\mathrm{CHCl}_{3}$. The organic layer was washed with brine and dried. After filtration and evaporation of the solvents, the residue was crystallized from ether to give $\mathbf{2 0}(3.0 \mathrm{~g}, 80 \%)$ as a colorless powder: ${ }^{1} \mathrm{H}-\mathrm{NMR}$ $\left(\mathrm{CDCl}_{3}\right) \delta: 2.99(3 \mathrm{H}, \mathrm{s}), 7.34(1 \mathrm{H}, \mathrm{t}, J=5 \mathrm{~Hz}), 8.57(1 \mathrm{H}, \mathrm{s}), 8.79(2 \mathrm{H}, \mathrm{d}$, $J=5 \mathrm{~Hz}), 10.08(1 \mathrm{H}, \mathrm{s})$.

2-[5-Methyl-4-[1-[(triethylsilyl)oxy]-3-butenyl]-1-1 H-imidazolyl]- 


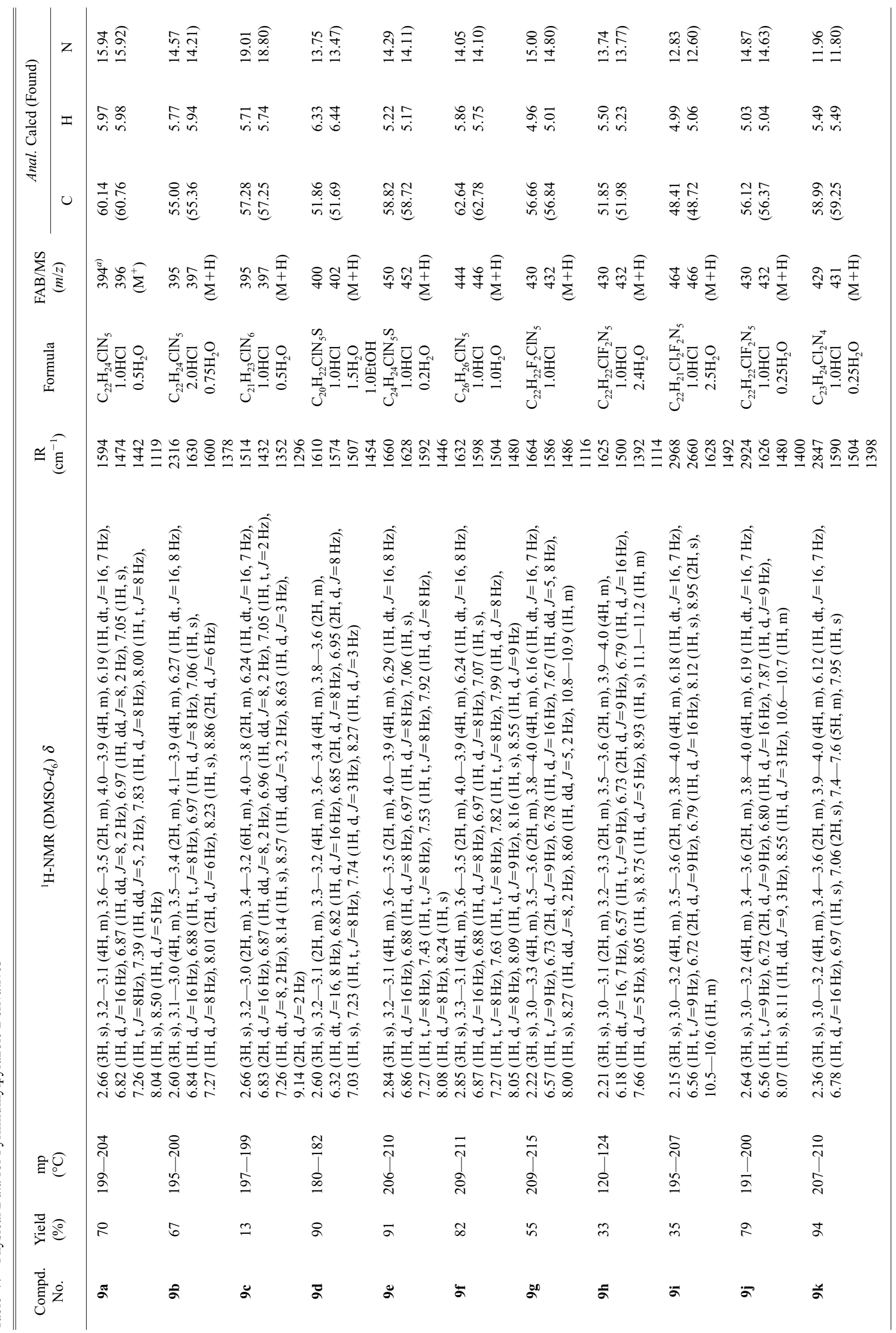




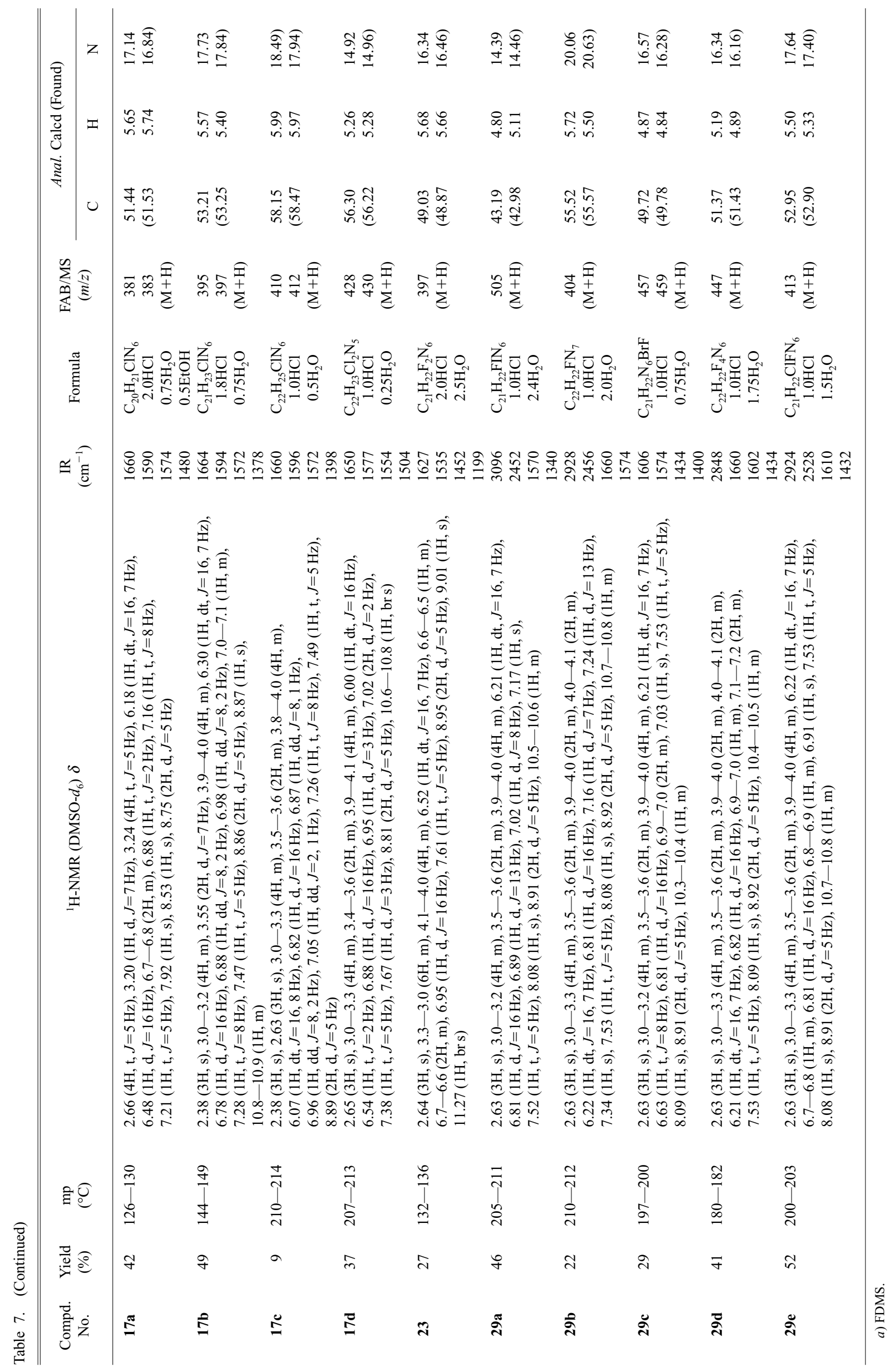


pyrimidine (21) Allyl bromide $(4.9 \mathrm{ml}, 57 \mathrm{mmol})$ and metallic tin $(2.2 \mathrm{~g}$, $19 \mathrm{mmol})$ were added to a solution of $20(3.0 \mathrm{~g}, 16 \mathrm{mmol})$ in THF $(50 \mathrm{ml})$ and water $(50 \mathrm{ml})$, and the mixture was sonicated for $2.5 \mathrm{~h}$ in an ultrasonic cleaning bath (Pasolina USC-1). The reaction mixture was carefully quenched with $1 \mathrm{~N}$ aqueous $\mathrm{HCl}(200 \mathrm{ml})$ at $0{ }^{\circ} \mathrm{C}$, diluted with $\mathrm{CHCl}_{3} / \mathrm{MeOH}$ (95/5), washed with brine, and dried. After removal of the solvents, the residue was chromatographed on a silica gel column $\left(\mathrm{CHCl}_{3} / \mathrm{MeOH}=98 / 2\right)$ to give the alcohol $(2.8 \mathrm{~g}, 77 \%)$ as a colorless amorphous solid: ${ }^{1} \mathrm{H}-\mathrm{NMR}$ $\left(\mathrm{CDCl}_{3}\right) \delta: 2.5-2.8(2 \mathrm{H}, \mathrm{m}), 2.59(3 \mathrm{H}, \mathrm{s}), 4.75(1 \mathrm{H}, \mathrm{dd}, J=13,7 \mathrm{~Hz}), 5.09$ $(1 \mathrm{H}, \mathrm{dd}, J=10,1 \mathrm{~Hz}), 5.16(1 \mathrm{H}, \mathrm{dd}, J=16,1 \mathrm{~Hz}), 5.83(1 \mathrm{H}, \mathrm{ddt}, J=16,10$ $7 \mathrm{~Hz}), 7.21(1 \mathrm{H}, \mathrm{t}, J=5 \mathrm{~Hz}), 8.51(1 \mathrm{H}, \mathrm{s}), 8.71(2 \mathrm{H}, \mathrm{d}, J=5 \mathrm{~Hz})$.

Imidazole $(1.5 \mathrm{~g}, 22 \mathrm{mmol})$ and chlorotetraethylsilane $(3.7 \mathrm{ml}, 22 \mathrm{mmol})$ were added successively to a solution of the above alcohol $(1.7 \mathrm{~g}, 7.3 \mathrm{mmol})$ in anhydrous DMF $(10 \mathrm{ml})$ at $0{ }^{\circ} \mathrm{C}$, and the mixture was stirred for $3.5 \mathrm{~h}$ at room temperature. Water $(30 \mathrm{ml})$ was added to the mixture, and the whole was extracted with AcOEt. The organic layer was washed with brine and dried. After removal of the solvents, the residue was chromatographed on a silica gel column $\left(\mathrm{CHCl}_{3} / \mathrm{MeOH}=99 / 1\right)$ to afford $\mathbf{1 3}(2.9 \mathrm{~g}$, quantitative yield) as a pale yellow oil: ${ }^{1} \mathrm{H}-\mathrm{NMR}\left(\mathrm{CDCl}_{3}\right) \delta: 0.5-0.6(6 \mathrm{H}, \mathrm{m}), 0.8-1.0$ $(9 \mathrm{H}, \mathrm{m}), 2.5-2.7(2 \mathrm{H}, \mathrm{m}), 2.62(3 \mathrm{H}, \mathrm{s}), 4.79(1 \mathrm{H}, \mathrm{t}, J=7 \mathrm{~Hz}), 4.99(1 \mathrm{H}, \mathrm{dt}$, $J=10 \mathrm{~Hz}), 5.06(1 \mathrm{H}, \mathrm{d}, J=17 \mathrm{~Hz}), 5.79(1 \mathrm{H}, \mathrm{ddt}, J=17,10,7 \mathrm{~Hz}), 7.19(1 \mathrm{H}$, $\mathrm{t}, J=5 \mathrm{~Hz}), 8.46(1 \mathrm{H}, \mathrm{s}), 8.70(2 \mathrm{H}, \mathrm{d}, J=5 \mathrm{~Hz})$

3-[5-Methyl-1-(2-pyrimidinyl)-4-1H-imidazolyl]-3-[(triethylsilyl)oxylpropanal (22) 4-Methylmorpholine $N$-oxide (NMO, $1.3 \mathrm{~g}, 11$ $\mathrm{mmol}$ ) and a catalytic amount of osmium tetraoxide were added to a solution of $21(1.9 \mathrm{~g}, 5.6 \mathrm{mmol})$ in THF $(25 \mathrm{ml})$ and water $(3.0 \mathrm{ml})$, and the mixture was stirred at room temperature for $4 \mathrm{~h}$. A suspension of sodium periodate $(5.9 \mathrm{~g}, 28 \mathrm{mmol})$ in water $(25 \mathrm{ml})$ was added to the above mixture at room temperature, and the mixture was stirred at the same temperature for $2 \mathrm{~h}$. The mixture was diluted with $\mathrm{CHCl}_{3}$, washed with brine, and dried. After removal of the solvents, the residue was chromatographed on a silica gel column $\left(\mathrm{CHCl}_{3} / \mathrm{MeOH}=99 / 1\right)$ to give $22(0.23 \mathrm{~g}, 12 \%)$ as a pale yellow oil: ${ }^{1} \mathrm{H}-\mathrm{NMR}\left(\mathrm{CDCl}_{3}\right) \delta: 0.5-0.6(6 \mathrm{H}, \mathrm{m}), 0.9-1.0(9 \mathrm{H}, \mathrm{m}), 2.64(3 \mathrm{H}, \mathrm{s})$, $2.87(1 \mathrm{H}$, ddd, $J=16,5,2 \mathrm{~Hz}), 3.07(1 \mathrm{H}$, ddd, $J=16,8,2 \mathrm{~Hz}), 5.31(1 \mathrm{H}, \mathrm{dd}$, $J=8,5 \mathrm{~Hz}), 7.22(1 \mathrm{H}, \mathrm{t}, J=5 \mathrm{~Hz}), 8.48(1 \mathrm{H}, \mathrm{s}), 8.71(2 \mathrm{H}, \mathrm{d}, J=5 \mathrm{~Hz}), 9.86$ $(1 \mathrm{H}, \mathrm{t}, J=2 \mathrm{~Hz})$.

3-[4-(3,5-Difluorophenyl)-1-piperazinyl]-1-[5-methyl-1-(2-pyrimidinyl)-4-1H-imidazolyl]-1-trans-propene Hydrochloride (23) AcOH (15 $\mu \mathrm{l}$, $1.3 \mathrm{mmol})$ and sodium cyanoborohydride $(82 \mathrm{mg}, 1.3 \mathrm{mmol})$ were added successively to a solution of $\mathbf{2 2}(89 \mathrm{mg}, 0.26 \mathrm{mmol})$ and $\mathbf{7 b}(0.25 \mathrm{~g}$, $1.3 \mathrm{mmol})$ in $\mathrm{EtOH}(10 \mathrm{ml})$, and the mixture was stirred at room temperature for $0.5 \mathrm{~h}$. The reaction mixture was diluted with $\mathrm{CHCl}_{3}$, washed with saturated aqueous $\mathrm{NaHCO}_{3}$ and brine, and dried. After removal of the solvents, the crude mixture was chromatographed on a silica gel column $\left(\mathrm{CHCl}_{3} / \mathrm{MeOH}=100 / 3\right)$ to afford the propene. An appropriate volume of a solution of $1 \mathrm{~N} \mathrm{HCl} / \mathrm{EtOH}$ was added to a solution of the propene in a small amount of EtOH, and the solvent was removed. The residue was recrystallized from EtOH to give $\mathbf{2 3}(28 \mathrm{mg}, 27 \%)$ as a colorless powder. The physical data for $\mathbf{2 3}$ are shown in Table 7.

1-Cyano-3-fluoro-5-nitrobenzene (24b) $\mathrm{CuCN}(5.0 \mathrm{~g}, 56 \mathrm{mmol})$ was added to a solution of 1-fluoro-3-iodo-5-nitrobenzene (24a, $15 \mathrm{~g}, 56 \mathrm{mmol})$ in DMF $(120 \mathrm{ml})$, and the mixture was heated to reflux for $3 \mathrm{~h}$. The mixture was diluted with ether, successively washed with $1 \mathrm{~N}$ aqueous $\mathrm{HCl}$, water, and brine, and then dried. Evaporation of the solvents afforded the crude mixture, which was chromatographed on a silica gel column (hexane/AcOEt $=50 / 3)$ to give $\mathbf{2 4 b}(8.0 \mathrm{~g}, 86 \%)$ as a pale yellow oil: ${ }^{1} \mathrm{H}$ $\operatorname{NMR}\left(\mathrm{CDCl}_{3}\right) \delta: 7.73(1 \mathrm{H}, \mathrm{dd}, J=7,2 \mathrm{~Hz}), 8.21(1 \mathrm{H}, \mathrm{dt}, J=8,2 \mathrm{~Hz}), 8.3-$ $8.4(1 \mathrm{H}, \mathrm{m})$

3-Fluoro-5-iodoaniline (25a) The suspension of 1-fluoro-3-iodo-5-nitrobenzene $(24 \mathrm{a}, 2.0 \mathrm{~g}, 7.5 \mathrm{mmol})$ and $\mathrm{SnCl}_{2} \cdot 2 \mathrm{H}_{2} \mathrm{O}(6.0 \mathrm{~g}, 26 \mathrm{mmol})$ in $\mathrm{EtOH}(30 \mathrm{ml})$ was heated to reflux for $1.5 \mathrm{~h}$. After removal of the solvent, the crude mixture was diluted with ether, washed with $4 \mathrm{~N}$ aqueous $\mathrm{NaOH}$ and brine, and dried. Evaporation of the solvents afforded the crude mixture, which was chromatographed on a silica gel column (hexane/AcOEt $=9 / 1)$ to give $25 \mathrm{a}(8.0 \mathrm{~g}, 86 \%)$ as an orange oil: ${ }^{1} \mathrm{H}-\mathrm{NMR}\left(\mathrm{CDCl}_{3}\right) \delta: 3.7-3.8(2 \mathrm{H}$, $\mathrm{m}), 6.32(1 \mathrm{H}, \mathrm{dt}, J=11,2 \mathrm{~Hz}), 6.7-6.9(1 \mathrm{H}, \mathrm{m}), 6.9-7.0(1 \mathrm{H}, \mathrm{m})$.

3-Cyano-5-fluoroaniline (25b) Compound $24 \mathrm{~b}(14 \mathrm{~g}, 85 \mathrm{mmol})$ was dissolved in $\mathrm{EtOH}(850 \mathrm{ml})$ and hydrogenated with $10 \% \mathrm{Pd} / \mathrm{C}(5.0 \mathrm{~g})$ under $\mathrm{H}_{2}$ atmosphere for $2 \mathrm{~h}$ at room temperature. The reaction mixture was filtered through a Celite pad and the filtrate was evaporated to afford the crude mixture, which was chromatographed on a silica gel column (hexane/ $\mathrm{AcOEt}=4 / 1)$ to give $25 \mathrm{~b}(8.5 \mathrm{~g}, 74 \%)$ as a pale yellow oil: ${ }^{1} \mathrm{H}-\mathrm{NMR}$ $\left(\mathrm{CDCl}_{3}\right) \delta: 4.0-4.1(2 \mathrm{H}, \mathrm{m}), 6.56(1 \mathrm{H}, \mathrm{dt}, J=10,2 \mathrm{~Hz}), 6.6-6.7(2 \mathrm{H}, \mathrm{m})$.

1-(3-Fluoro-5-iodophenyl)piperazine (27a) A mixture of 25a (1.4 g,
$6.0 \mathrm{mmol})$ and bis(2-chloroethyl)amine hydrochloride $(1.1 \mathrm{~g}, 6.1 \mathrm{mmol})$ in $n$ $\mathrm{BuOH}(15 \mathrm{ml})$ was refluxed for $45 \mathrm{~h}$. Anhydrous sodium carbonate $(0.83 \mathrm{~g}$, $6.0 \mathrm{mmol}$ ) was added to the mixture. After being stirred for $26 \mathrm{~h}$, the reaction mixture was diluted with $\mathrm{CHCl}_{3}$, successively washed with $1 \mathrm{~N}$ aqueous $\mathrm{NaOH}$, water, and brine, and then dried. Evaporation of the solvents afforded the crude mixture, which was chromatographed on a silica gel column $\left(\mathrm{CHCl}_{3} / \mathrm{MeOH}=20 / 1\right)$ to give $27 \mathrm{a}(0.53 \mathrm{~g}, 28 \%)$ as an orange oil. Compounds $\mathbf{2 5} \mathbf{b}$ - $\mathbf{d}$ were treated in the same manner as described above to give 27b-d, respectively.

27a: Yield $28 \%$, an orange oil. ${ }^{1} \mathrm{H}-\mathrm{NMR}\left(\mathrm{CDCl}_{3}\right) \delta: 3.0-3.1(4 \mathrm{H}, \mathrm{m})$, $3.1-3.2(4 \mathrm{H}, \mathrm{m}), 6.52(1 \mathrm{H}, \mathrm{dd}, J=12,2 \mathrm{~Hz}), 6.87(1 \mathrm{H}, \mathrm{dd}, J=7,2 \mathrm{~Hz})$ $6.9-7.0(1 \mathrm{H}, \mathrm{m})$.

27b: Yield $23 \%$, a pale yellow oil. ${ }^{1} \mathrm{H}-\mathrm{NMR}\left(\mathrm{CDCl}_{3}\right) \delta$ : $3.0-3.1(4 \mathrm{H}, \mathrm{m})$, $3.1-3.2(4 \mathrm{H}, \mathrm{m}), 6.75(1 \mathrm{H}, \mathrm{d}, J=2 \mathrm{~Hz}), 6.7-6.8(1 \mathrm{H}, \mathrm{m}), 6.9-7.0(1 \mathrm{H}$, $\mathrm{m})$.

27c: Yield $19 \%$, a pale yellow powder. ${ }^{1} \mathrm{H}-\mathrm{NMR}\left(\mathrm{CDCl}_{3}\right) \delta: 3.00(4 \mathrm{H}$, dd, $J=5,3 \mathrm{~Hz}), 3.14(4 \mathrm{H}, \mathrm{dd}, J=5,3 \mathrm{~Hz}), 6.50(1 \mathrm{H}, \mathrm{dt}, J=12,2 \mathrm{~Hz}), 6.68(1 \mathrm{H}$, $\mathrm{dt}, J=8,2 \mathrm{~Hz}), 6.79(1 \mathrm{H}, \mathrm{s})$.

27d: Yield $30 \%$, a pale yellow oil. ${ }^{1} \mathrm{H}-\mathrm{NMR}\left(\mathrm{CDCl}_{3}\right) \delta: 3.0-3.1(4 \mathrm{H}, \mathrm{m})$, $3.2-3.3(4 \mathrm{H}, \mathrm{m}), 6.71(1 \mathrm{H}, \mathrm{dd}, J=12,2 \mathrm{~Hz}), 6.74(1 \mathrm{H}, \mathrm{dd}, J=10,2 \mathrm{~Hz})$, $6.8-6.9(1 \mathrm{H}, \mathrm{m})$.

1-(3-Chloro-5-fluorophenyl)piperazine (27e) Piperazine $(25 \mathrm{~g}, 0.29$ $\mathrm{mol})$, dichlorobis(tri-o-tolylphosphine)palladium $(1.7 \mathrm{~g}, 2.2 \mathrm{mmol})$, and sodium tert-butoxide $(9.6 \mathrm{~g}, 0.10 \mathrm{~mol})$ were added to a solution of 1-bromo3-chloro-5-fluorobenzene $(\mathbf{2 6}, 15 \mathrm{~g}, 72 \mathrm{mmol})$ in toluene $(350 \mathrm{ml})$, and the mixture was stirred at $100^{\circ} \mathrm{C}$ for $38 \mathrm{~h}$. The reaction mixture was washed with water and brine, and dried. After removal of the solvents, the crude mixture was chromatographed on a silica gel column $\left(\mathrm{CHCl}_{3} / \mathrm{MeOH}=93 / 7\right)$ to afford $27 \mathrm{e}(5.7 \mathrm{~g}, 37 \%)$ as a pale yellow oil: ${ }^{1} \mathrm{H}-\mathrm{NMR}\left(\mathrm{CDCl}_{3}\right) \delta: 2.8-$ $3.2(4 \mathrm{H}, \mathrm{m}), 3.0-3.3(4 \mathrm{H}, \mathrm{m}), 6.46(1 \mathrm{H}, \mathrm{dt}, J=12,2 \mathrm{~Hz}), 6.53(1 \mathrm{H}, \mathrm{dt}, J=8$, $2 \mathrm{~Hz}), 6.6-6.7(1 \mathrm{H}, \mathrm{m})$.

3-[4-(3-Fluoro-5-iodophenyl)-1-piperazinyl]-1-[5-methyl-1-(2-pyrimidinyl)-4-(1H)-pyrazolyl]-1-propanone (28a) Synthesis of 28a-e from $\mathbf{2 7 a - e}$ with $\mathbf{1 3}$ was performed as described for the synthesis of $\mathbf{8 a}$. The physical data for $\mathbf{2 8 a}-\mathbf{e}$ are shown in Table 6 .

3-[4-(3-Fluoro-5-iodophenyl)-1-piperazinyl]-1-[5-methyl-1-(2-pyrimidinyl)-4-(1H)-pyrazolyl]-1-trans-propene Hydrochloride (29a) Synthesis of 29a- $\mathbf{e}$ from $28 \mathbf{a}-\mathbf{e}$ was performed as described for the synthesis of 9a. The physical data for $\mathbf{2 9} \mathbf{a}-\mathbf{e}$ are shown in Table 7 .

In Vitro Cytotoxicity To examine the direct growth-inhibitory effects of the test compounds against PC-6 and PC-12 human non-small cell lung cancer cell lines and resistant cell lines, ${ }^{19)}$ the 3-(4,5-dimethylthiazol-2-yl)-2,5diphenyltetrazolium bromide (MTT) assay was performed, and the concentration giving a growth inhibition of $50 \%\left(\mathrm{GI}_{50}\right)$ was calculated according to a published procedure. ${ }^{22)}$

Evaluation of Therapeutic Effect in Vivo Meth A murine fibrosarcoma cells $\left(1 \times 10^{6}\right)$ were implanted into the right flank of BALB/c mice (day 0). Compounds were administered p.o. on days 7-11, consecutively. Tumor weights were measured on day 17. Human non-small cell lung cancer PC-12 and PC-14 blocks were inoculated s.c. into BALB/cAnNCrj-nu mice (day 0). Compounds at the indicated doses were administered per os (oral) administration (p.o.) on days $11-14$ and $17-20$, or on days $14-17$ and $21-24$. VCR was administrated i.v. on day 11 or 14 , once. The tumor growth-inhibition rate (IR) was calculated by the formula: IR $(\%)=(1-\mathrm{TWt} / \mathrm{TWc}) \times 100(\%)$, where $\mathrm{TWt}$ represents the mean tumor weight of a treated group, and TWc represents that of the control group. To evaluate the intensity of the side effects of the compounds, the rate of body weight loss (BWL) was utilized as a parameter of toxicity. The maximum value of BWL was designated as BWLmax, and a BWLmax of less than zero indicates no body weight loss.

\section{References and Notes}

1) Naito H., Sugimori M., Mitsui I., Nakamura Y., Ishii M., Iwahana M., Hirotani K., Kumazawa E., Ejima A., Chem. Pharm. Bull., 47, 16791684 (1999).

2) Naito H., Ohsuki S., Sugimori M., Atsumi R., Minami M., Nakamura Y., Ishii M., Hirotani K., Kumazawa E., Ejima A., Chem. Pharm. Bull., 50, 453-462 (2002).

3) Compounds $\mathbf{5 a}, \mathbf{b}, \mathbf{e}, \mathbf{f}, \mathbf{g}$, and $\mathbf{i}$ were commercially available.

4) The synthesis of $\mathbf{5 c}$; Spingarn N. E., Sartorelli A. C., J. Med. Chem., 22, 1314-1316 (1979).

5) The synthesis of 5d; Lee A. L., Mackay D., Manery E. L., Can. J. Chem., 48, 3554-3562 (1970).

6) The synthesis of $\mathbf{5 h}$; Fleet G. W. J., Fleming I., J. Chem. Soc. C, 1969 , 
1758 - 1762 (1969).

7) The synthesis of $\mathbf{5 j}$; Easmon J., Heinisch G., Puerstinger G., Langer T., Oesterreicher J. K., Grunicke H. H., Hofmann J., J. Med. Chem., 40, 4420 - 4425 (1997).

8) Wang J.-H., Shen Y.-Q., Yu C.-X., Si J.-H., J. Chem. Soc. Perkin Trans. $1,9,1455-1460$ (2000).

9) Menichi G., Boutar M., Kokel B., Takagi K., Hubert-Habart M., J. Heterocycl. Chem., 23, 275-279 (1986).

10) Schenone P., Mosti L., Menozzi G., J. Heterocycl. Chem., 19, 13551361 (1982).

11) Ikeda M., Maruyama K., Nobuhara Y., Yamada T., Okabe S., Chem. Pharm. Bull., 44, 1700-1706 (1996).

12) Echavarren A. M., Still J. K., J. Am. Chem. Soc., 109, 5478-5486 (1987).

13) Konishi K., Kuragano T., Nippon Noyaku Gakkaishi, 15, 13-22 (1990).

14) Alberola A., Gonzalez Ortega A., Sadaba M. L., Sanudo C., Tetrahe- dron, 55, 6555-6566 (1999).

15) Wee A. G. H., Shu A. Y. L., Bunnenberg E., Djerassi C., J. Org. Chem., 49, 3327-3336 (1984).

16) Mukaiyama T., Harada T., Chem. Lett., 1527-1528 (1981).

17) Zhao S.-H., Miller A. K., Berger J., Flippin L. A., Tetrahedron Lett., 37, 4463-4466 (1996).

18) Barr W. H., Riegelman S., J. Pharm. Sci., 59, 154-163 (1970).

19) Ishii M., Iwahana M., Mitsui I., Minami M., Imagawa S., Tohgo A., Ejima A., Anti-Cancer Drugs, 11, 353-362 (2000).

20) Ohki H., Hirotani K., Naito H., Ohsuki S., Minami M., Ejima A., Koiso Y., Hashimoto Y., Bioorg. Med. Chem. Lett., 12, 3191-3193 (2002).

21) Iwahana M., Ochi Y., Ejima A., Anticancer Res., 20, 785-792 (2000).

22) Mitsui I., Kumazawa E., Aonuma M., Sugimori M., Ohsuki S., Uoto K., Ejima A., Terasawa H., Sato K., Jpn. J. Cancer Res., 86, 776-782 (1995). 